\title{
St. Vincent and the Grenadines: 2005 Article IV Consultation-Staff Report; and Public Information Notice on the Executive Board Discussion
}

Under Article IV of the IMF's Articles of Agreement, the IMF holds bilateral discussions with members, usually every year. In the context of the 2005 Article IV consultation with St. Vincent and the Grenadines, the following documents have been released and are included in this package:

- the staff report for the 2005 Article IV consultation, prepared by a staff team of the IMF, following discussions that ended on April 13, 2005, with the officials of St. Vincent and the Grenadines on economic developments and policies. Based on information available at the time of these discussions, the staff report was completed on June 23, 2005. The views expressed in the staff report are those of the staff team and do not necessarily reflect the views of the Executive Board of the IMF.

- $\quad$ a Public Information Notice (PIN) summarizing the views of the Executive Board as expressed during its July 13, 2005 discussion of the staff report that concluded the Article IV consultation.

The document listed below have been or will be separately released.

Statistical Appendix

The policy of publication of staff reports and other documents allows for the deletion of market-sensitive information.

To assist the IMF in evaluating the publication policy, reader comments are invited and may be sent by e-mail to publicationpolicy@imf.org.

\author{
Copies of this report are available to the public from \\ International Monetary Fund • Publication Services \\ $70019^{\text {th }}$ Street, N.W. • Washington, D.C. 20431 \\ Telephone: (202) 623-7430 • Telefax: (202) 623-7201 \\ E-mail: publications@imf.org • Internet: http://www.imf.org
}

Price: $\$ 15.00$ a copy

\section{International Monetary Fund \\ Washington, D.C.}




\title{
INTERNATIONAL MONETARY FUND
}

\section{ST. VINCENT AND THE GRENADINES}

\section{Staff Report for the 2005 Article IV Consultation}

\author{
Prepared by the Staff Representatives for the 2005 Consultation \\ with St. Vincent and the Grenadines
}

Approved by Ratna Sahay and Matthew Fisher

June 23, 2005

\begin{abstract}
Economic Background: St. Vincent and the Grenadines is a 32-island economy in the eastern Caribbean, with a population of about 106,300 and per capita GDP of US\$3,800. It is one of eight eastern Caribbean countries and territories comprising the Eastern Caribbean Currency Union (ECCU), and its GDP accounts for 13 percent of the combined ECCU GDP. The ECCU has a common central bank, the Eastern Caribbean Central Bank (ECCB), and a common currency, the Eastern Caribbean (EC) dollar. The EC dollar has been pegged to the U.S. dollar at the rate of EC $\$ 2.70$ per U.S. dollar since July 1976. St. Vincent and the Grenadines has accepted the obligations of Article VIII, Sections 2, 3, and 4, and maintains an exchange system free of restrictions on payments and transfers for current international transactions. Fund relations are summarized in Appendix I.

Political Situation: St. Vincent and the Grenadines has a unicameral parliament consisting of 21 members-15 elected and 6 appointees. Prime Minister Ralph Gonsalves' Unity Labour Party assumed power following the March 2001 elections, in which it defeated the National Democratic Party (which had been in power since 1984) by winning 12 out of the 15 contested seats in Parliament. Elections are due no later than March 2006, but it is likely that elections will be held in the second half of 2005.
\end{abstract}

Previous Board Discussion: The last Article IV consultation was completed on May 5, 2004. The public information notice (PIN), which contains the summing up of Executive Directors' discussions and policy recommendations, can be found at the IMF website at: http://www.imf.org/external/np/sec/pn/2005/pn0565.htm.

Mission: A staff mission comprising P. Cashin (Head), M. Mlachila, P. Mishra (all WHD), and D. Nyberg (FIN) visited Kingstown during April 5-13, 2005. Staff met with the Prime Minister (and Minister of Finance), the Director General of the Ministry of Finance, other senior government officials, representatives of the banking, agriculture, and business sectors, as well as trade unions and civil society. Staff of the ECCB and CDB also participated in the meetings. K. Lynch and R. Campbell (OED), and R. Sahay and D. Robinson (WHD) joined staff for the final discussions, which also overlapped with the ECCU Regional Discussions with St. Vincent and the Grenadines. 


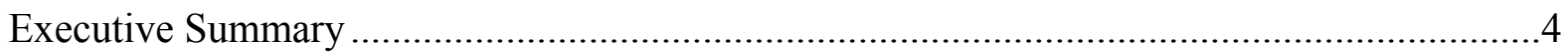

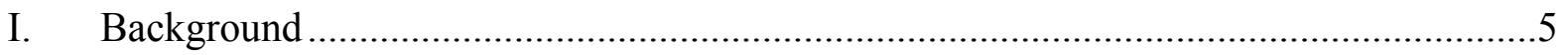

II. Recent Economic Developments and Near-Term Prospects .....................................8

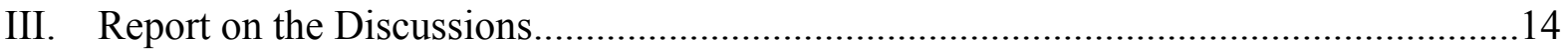

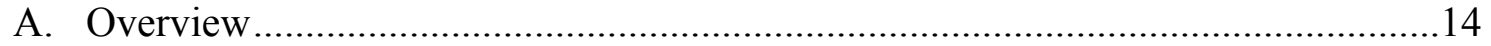

B. Enhancing Growth Potential and Alleviating Poverty.......................................15

C. Debt Sustainability and Fiscal Policy ........................................................... 18

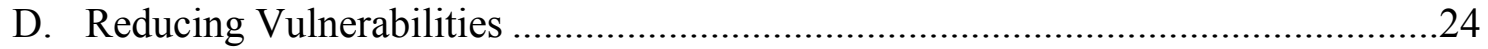

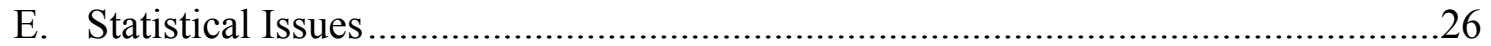

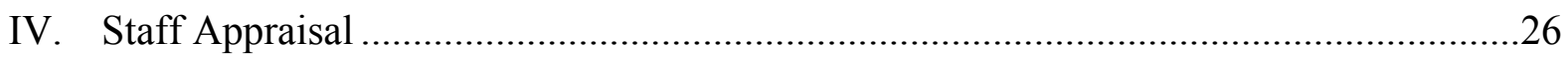

Boxes

1. Summary of Approved 2005 Budget ..................................................................... 11

2. Poverty Indicators and Poverty Reduction Strategy ...........................................20

Figures

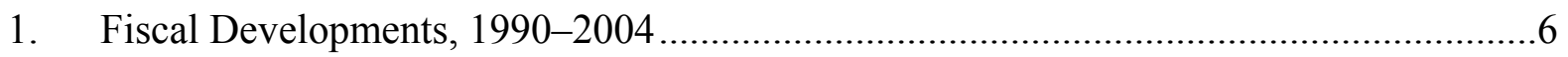

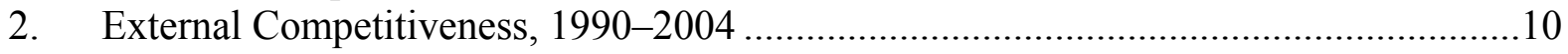

3. Banking System Developments, 1998-2004 …...................................................... 13

Tables

1. Selected Social and Economic Indicators, 2000-2005 ..........................................29

2. Summary of Central Government Operations, 2001-2010 ......................................30

3. Summary of Central Government Operations, 2001-2010 .......................................31

4. Balance of Payments Summary 2000-2010 (Active Scenario) ...................................32

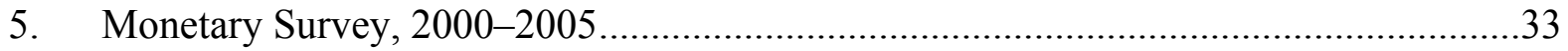

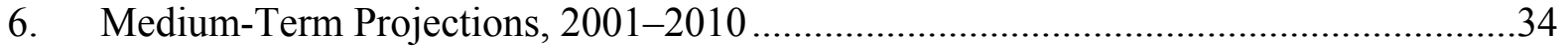

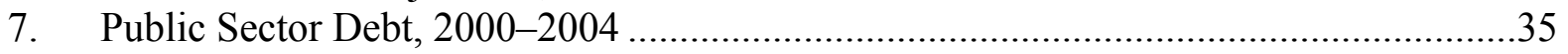

8. Public Sector Debt Sustainability Framework, 2000-2010 .......................................36

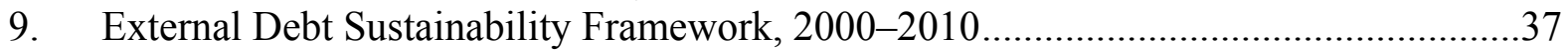

10. Indicators of External and Financial Vulnerability, 2000-2005 ................................38

11. Millennium Development Goals Country Profile...................................................39

Annexes

I. Preferential Trade Arrangement in Bananas ............................................................40

II. Medium-Term Outlook Under Alternative Fiscal Scenarios....................................42 


\section{Appendices}

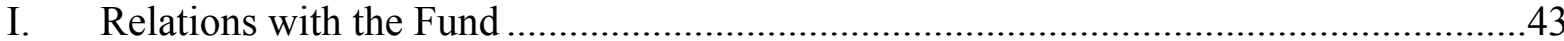

II. Relations with the World Bank Group ...........................................................46

III. Relations with the Caribbean Development Bank ........................................................49

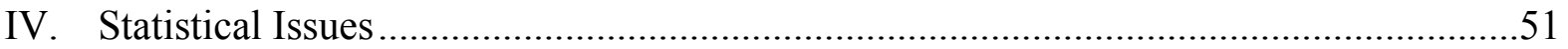




\section{EXECUTIVE SUMMARY}

Rapid economic growth in the 1980s was followed by a sluggish growth performance since the early 1990s. Growth has slowed due to the erosion of trade preferences, poor weather and natural disasters, the September 11 shock, and a decline in overseas development assistance. While traditionally among the most fiscally responsible of the ECCU countries, to accelerate growth the authorities began in the late 1990s to implement expansionary fiscal policies. This growth in public sector imbalances engendered a rise in the stock of public debt to almost 80 percent of GDP in 2004.

Economic activity in St. Vincent and the Grenadines has strengthened, with real GDP growing by over 4 percent in 2004 and further acceleration expected in 2005. This improved performance was underpinned by a supportive external environment in tourism, an increase in public sector investment, and a rebound in construction and agriculture sectors. However, fiscal imbalances expanded in 2004 and under current policies will rise further in 2005. The approved budget for 2005 is likely to lead to a significant deterioration in the fiscal accounts if fully implemented.

Prudential indicators point to weaknesses in the banking sector, although efforts are ongoing to strengthen bank balance sheets. Indigenous banks suffer from a number of weaknesses, including total capital-to-risk-weighted assets that are considerably below the ECCU average, a large portfolio of nonperforming loans, and high public sector exposures.

The discussions focused on measures to significantly reduce poverty and bring St. Vincent and the Grenadines' income level closer to that of its ECCU counterparts, by enhancing growth potential, making debt more sustainable and reducing vulnerabilities. In the absence of a strong effort to tackle the growing fiscal imbalances, the stock of debt could be placed on an unsustainable path. The high level of debt raises the risk from adverse shocks, constrains the government's future ability to engage in counter-cyclical policy, and crowds out expenditure on the achievement of important social and economic goals.

Fiscal adjustment of $2 \frac{1}{2}$ percent of GDP in 2005 is needed as a first step in closing the fiscal imbalances. This would be largely achieved by expenditure reductions, through cuts to the civil service wage bill, transfers, and limiting capital expenditure to well-targeted projects. Over the medium term, efforts should be made to broaden the tax base (through the introduction of a value-added tax and market-based property taxes), reduce tax concessions, and allow domestic retail prices for energy products to reflect world prices.

St. Vincent and the Grenadines is vulnerable to both natural disasters and adverse financial sector shocks. To reduce weather-related vulnerabilities, the authorities should further boost expenditure on disaster mitigation and preparedness, and their efforts to transfer disaster risk. The prudential and regulatory framework of the financial sector has been strengthened in recent years - further enhancements would reduce vulnerabilities in the financial sector, particularly those facing local banks with high exposure to the public sector and a large portfolio of nonperforming loans. 


\section{BACKGROUND}

1. St. Vincent and the Grenadines is a small, open economy whose mainstay is a largely tourism-based services sector. The export-oriented services sector accounts for about three-quarters of total value added, and the import content of both domestic consumption and investment is high. While the traditionally-dominant agriculture sector has declined in recent decades, agricultural crops (particularly bananas) remain important in sustaining the incomes of the country's large rural population.

\section{Real economic growth in the $1990 \mathrm{~s}$ and $2000 \mathrm{~s}$ was considerably less than that of} the 1980s. Factors inhibiting the growth performance in the 1990s include: temporary shocks (economic disruption caused by poor weather, natural disasters, and the September 11 shock to world tourism), and permanent shocks (the erosion of trade preferences and slump in overseas development assistance flows). Economic growth has rebounded since its trough in 2001, but is still far below that attained in the 1980s.

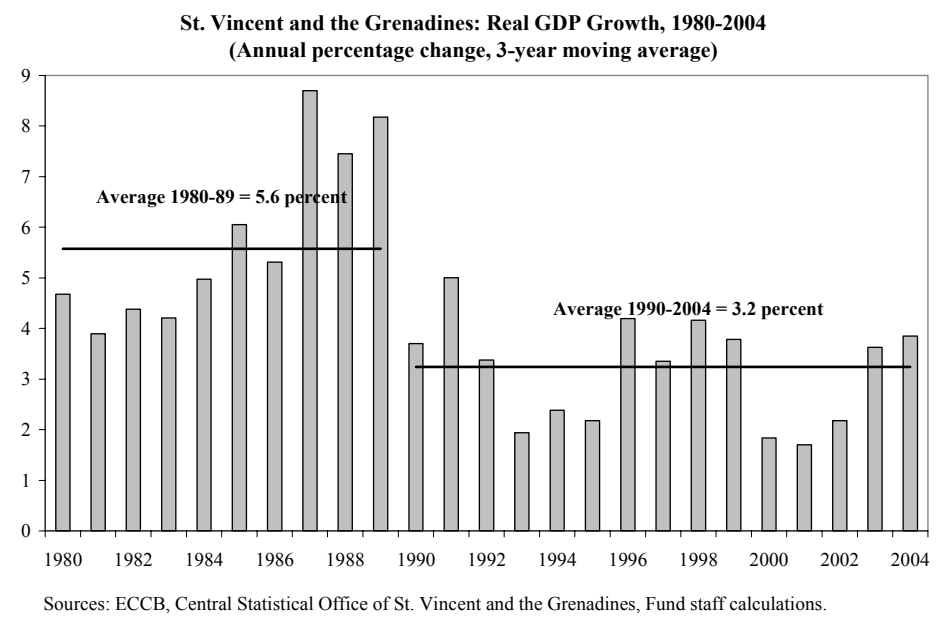

3. The fiscal situation has weakened since the late 1990s, and public debt has risen rapidly since 1999, yet remains lower than the ECCU average (Figure 1). While traditionally among the most fiscally responsible of the ECCU countries, to accelerate growth the authorities began in the late 1990s to implement expansionary fiscal policies. This fiscal laxity was compounded by the cost of rehabilitation expenditures to repair damage caused by a series of weather-induced disasters. Public debt rose from less than 50 percent of GDP in 1997 to reach 79 percent of GDP by 2004, in large part due to the assumption by the government in 1999 of private debt for the construction of the Ottley Hall shipyard. ${ }^{1}$ Reflecting this accretion of public liabilities, as well as a result of increasingly less

\footnotetext{
${ }^{1}$ In 1999 the government assumed a large private external debt of EC\$156 million (amounting to 171/2 percent of GDP) for the construction of Ottley Hall shipyard (a yacht repair facility). The shipyard was operated by a joint-venture company, Caribbean Charter and Yacht Yard Holdings, owned by the government (49 percent) and a private company, the St. Vincent Yachting and Shipping Company (51 percent). The government had guaranteed the debt. In 2001 the government obtained a moratorium on interest payments pending a settlement with creditors (foreign commercial banks), and continues to seek a debt restructuring. The Italian export guarantee agency, SACE, which insured the external financiers, is currently servicing the loan.
} 
Figure 1. St. Vincent and the Grenadines: Fiscal Developments, 1990-2004

(In percent of GDP, unless otherwise denoted)

There has been a sharp increase in expenditures since $1997 .$.

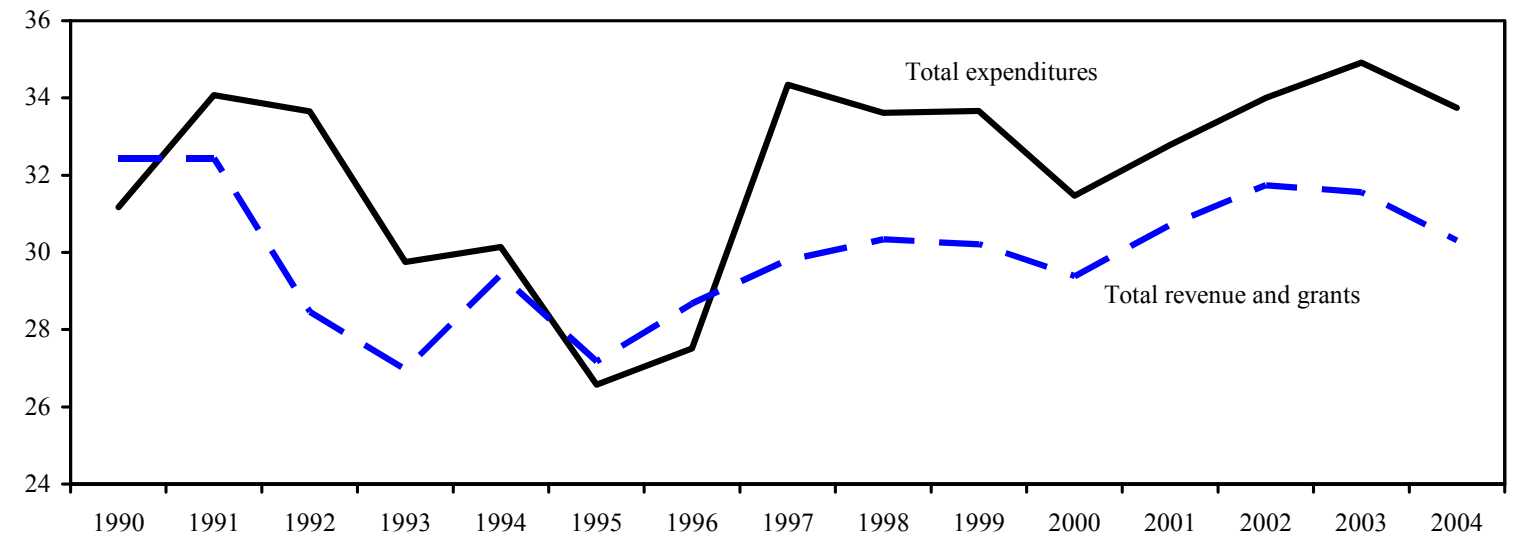

...with persistent fiscal deficits, and the public assumption of a private external loan in 1999...

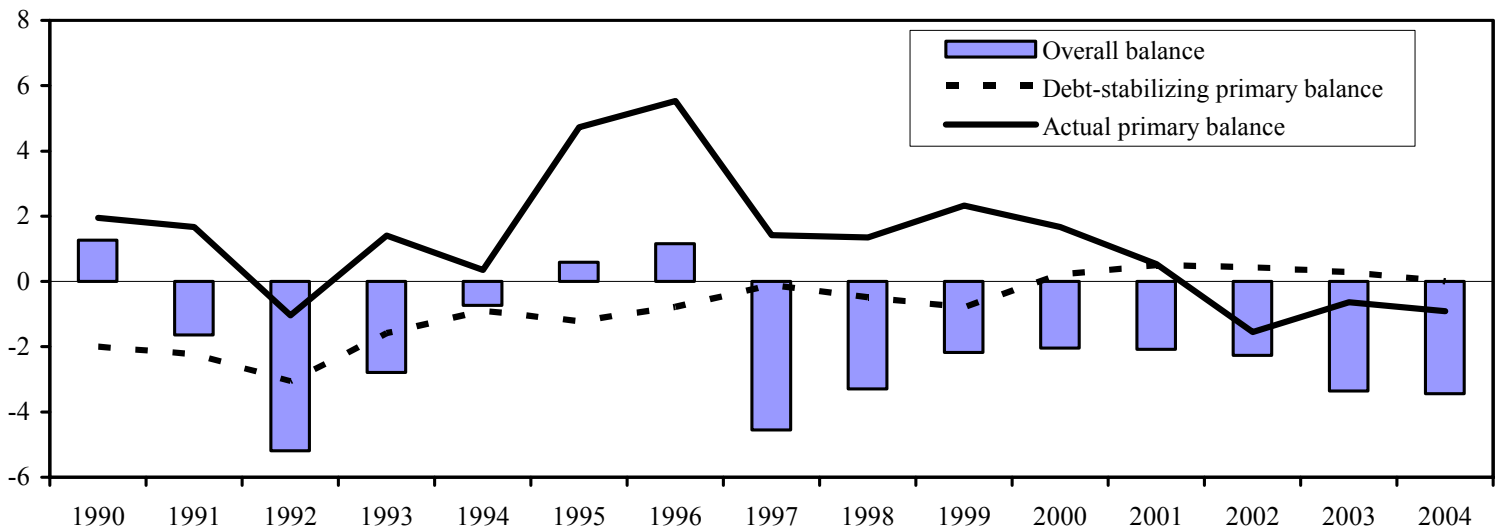

...yielding a rise in both the public stock of debt and the cost of debt servicing.

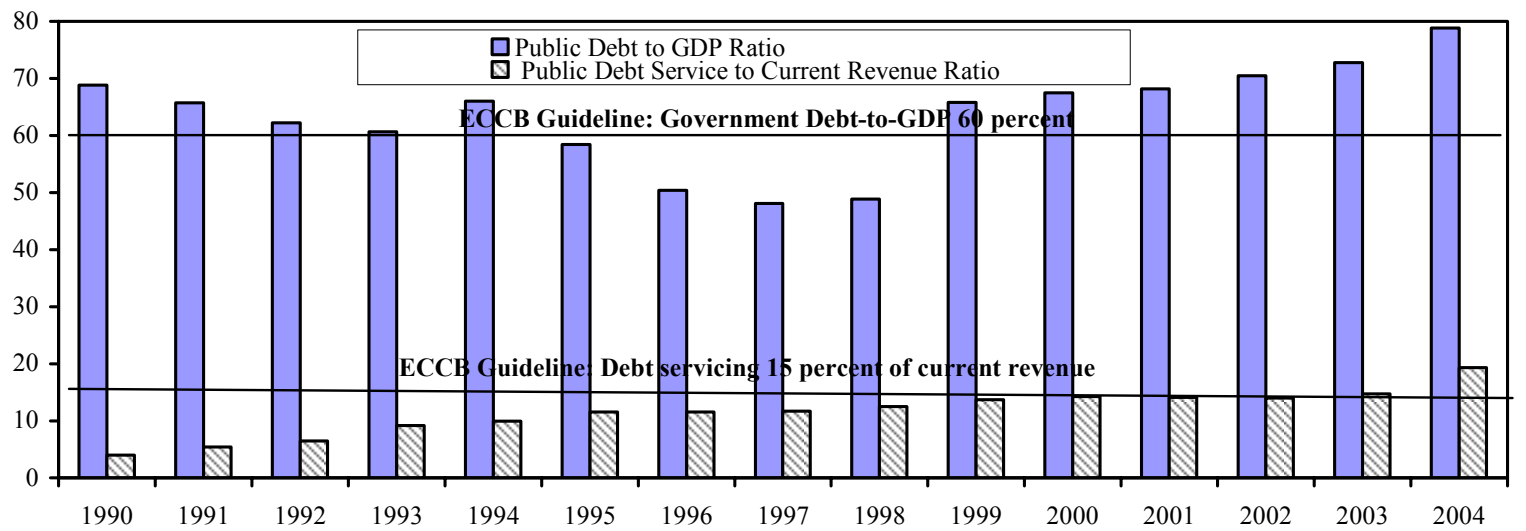

Sources: St. Vincent and the Grenadines authorities; and Fund staff estimates. 
concessional borrowing, debt service as a proportion of revenue has steadily increased over time, reaching 19 percent in 2004.

\section{St. Vincent and the Grenadines is the poorest country in the ECCU, yet has} generally strong social indicators. Building on the home-grown Interim Poverty Reduction Strategy Paper (I-PRSP), the government has recently developed a "Social Contract" intended to enhance participatory democracy in public policymaking and the implementation of povertyalleviation measures. St. Vincent and the Grenadines exhibits high adult literacy, has the same average life expectancy at birth as the ECCU average, yet twofifths of the population lives in poverty.

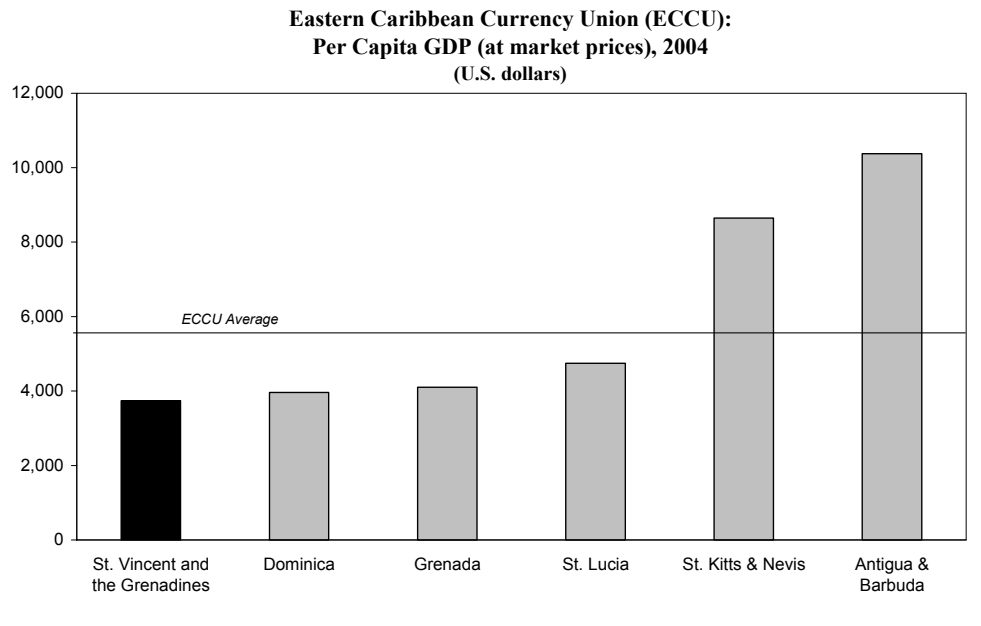

\section{Parliamentary elections are due no later than March 2006, yet are widely} expected to be called in the second half of 2005. The current government, led by Prime Minister Dr. Ralph Gonsalves and his Unity Labour Party (ULP), has been in power since the March 2001 general elections and controls 12 out of 15 contested seats in Parliament.

Dr. Gonsalves' stated priorities include the importance of inclusiveness in policymaking, and the need to tackle unemployment and poverty through various public programs and projects, such as the

St. Vincent and the Grenadines: Social and Demographic Indicators

\begin{tabular}{lcc}
\hline & $\begin{array}{c}\text { St. Vincent and } \\
\text { the Grenadines }\end{array}$ & ECCU \\
\hline Population (in thousand), estimate 2001 & 106 & 568 \\
Poverty headcount index , 2001 1/ & 38 & 29 \\
HDI rank, out of 177 countries, 2004 & 87 & 73 \\
Life expectancy at birth (years), 2003 & 73 & 74 \\
Adult illiteracy rate (percent), 2001 & 11 & 8 \\
AIDS incidence per 100,000, 1998 & 38 & 14 \\
Immunization coverage (percent), 2000 & 95 & 93 \\
Per capita energy availability (calories per day) & 2,535 & 2,695 \\
Infant mortality rate (per 100,000 live births), 2003 & 23 & 17 \\
GDP per capita (US\$) in 2004, estimate & 3,801 & 5,473 \\
& & \\
\hline
\end{tabular}

1/ Percentage of population living below each country's locally-defined poverty line. construction of low-income housing and the provision of universal secondary education. He has also advocated removing customs and immigration barriers within CARICOM, and is in favor of greater regional cooperation and integration. 


\section{Recent Economic Developments ANd Near-Term Prospects}

6. Economic activity has strengthened, with real GDP growing by over 4 percent in 2004 and further acceleration expected in 2005. ${ }^{2}$ Domestic factors have contributed to the strengthened outcomes, in particular, the increase in public sector investment and sustained activity in the construction sector. A favorable external environment has also boosted growth - there has been a revival of tourism (10 percent increase in stay-over arrivals in 2004). Growth for 2005 as a whole is expected to reach about 5 percent on the basis of continued expansion in tourism and tourism-related services, a rebound in agricultural production, as well as the ongoing high level of construction activity.

7. Despite a virtually unchanged overall fiscal position compared to 2003, the debt situation deteriorated significantly in 2004. The primary balance of the central government deteriorated from a deficit of 0.6 percent of GDP in 2003 to a deficit of 0.9 percent in 2004 , with the overall deficit unchanged at $3 \frac{1}{2}$ percent of GDP in 2004. Nonetheless, public sector debt increased substantially to 79 percent of GDP at end-2004, mainly due to the contracting of new debt in anticipation of major new public investment projects and programs.

\section{The approved budget for $\mathbf{2 0 0 5}$ is likely to lead to a significant deterioration in the fiscal accounts if fully implemented. The budget envisages a large increase in}

\footnotetext{
${ }^{2}$ Economic growth remained healthy in 2004, despite the adverse effects of Hurricane Ivan on economic activity. Ivan, which passed close to St. Vincent and the Grenadines in September 2004, caused damage (equivalent to about 5 percent of 2003 GDP) to the country's banana and agricultural crops, as well as to private housing and some public infrastructure.
}

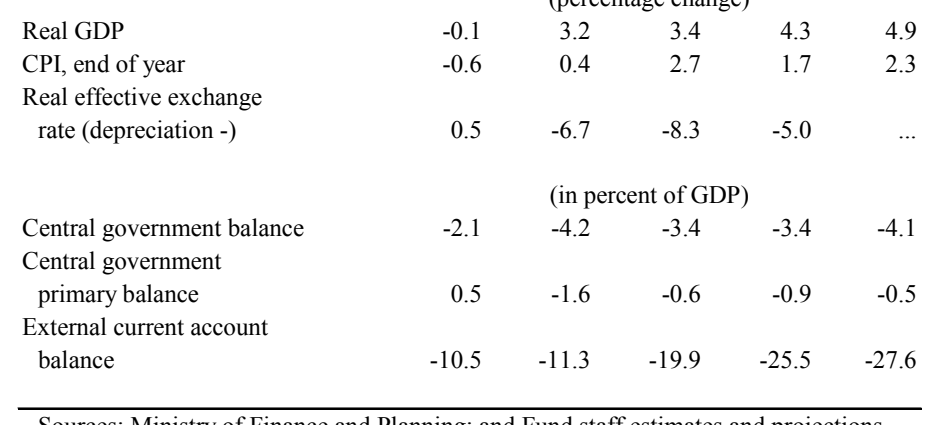

Sources: Ministry of Finance and Planning; and Fund staff estimates and projections. 
discretionary spending, especially in current expenditure, without a commensurate increase in revenues, entailing a further increase in debt levels (Box 1). Absent any new measures, the primary balance (as a share of GDP) is expected to deteriorate by about 2 percent in 2005, and the overall balance will attain a deficit of $6 \frac{1}{2}$ percent of GDP. However, based on limited implementation capacity and historical norms for the execution rate of capital investment (which averaged 47 percent over the past five years), not all budgeted expenditures should materialize.

\section{The external current} account deficit widened substantially in 2004, and is likely to deteriorate further in 2005. The large rise in the

Summary of Central Government Operations, 2001-05 (In percent of GDP, unless otherwise stated)

\begin{tabular}{|c|c|c|c|c|c|c|}
\hline & \multirow[b]{2}{*}{2001} & \multirow[b]{2}{*}{2002} & \multirow[b]{2}{*}{2003} & \multicolumn{3}{|c|}{ Current } \\
\hline & & & & $\begin{array}{c}\text { Est. } \\
2004\end{array}$ & $\begin{array}{l}\text { Policies } 1 / \\
2005\end{array}$ & $\begin{array}{c}\text { Active } \\
2005\end{array}$ \\
\hline Total revenue and grants & 30.7 & 31.7 & 31.6 & 30.3 & 31.8 & 31.7 \\
\hline Current revenue & 28.7 & 30.6 & 31.0 & 29.5 & 30.0 & 30.1 \\
\hline Grants & 1.9 & 1.1 & 0.4 & 0.7 & 1.7 & 1.6 \\
\hline Total expenditure and net lending & 32.8 & 34.0 & 34.9 & 33.7 & 38.3 & 35.8 \\
\hline Current & 27.7 & 28.0 & 26.9 & 26.4 & 29.3 & 27.5 \\
\hline Capital expenditure & 5.0 & 6.4 & 8.0 & 7.3 & 8.9 & 8.3 \\
\hline Net lending & 0.0 & -0.4 & 0.0 & 0.0 & 0.0 & 0.0 \\
\hline Current balance (before grants) & 1.0 & 2.6 & 4.1 & 3.1 & 0.7 & 2.6 \\
\hline $\begin{array}{l}\text { Overall balance (cash basis) } \\
\text { Of which }\end{array}$ & -2.1 & -4.2 & -3.4 & -3.4 & -6.5 & -4.1 \\
\hline Primary balance & 0.5 & -1.6 & -0.6 & -0.9 & -2.7 & -0.5 \\
\hline Gross central government debt (in percent of GDP) & 65.5 & 68.3 & 68.2 & 70.9 & 73.1 & 70.8 \\
\hline Public sector debt (in percent of GDP) & 68.2 & 70.5 & 72.8 & 78.9 & 83.9 & 81.3 \\
\hline Debt service as a proportion of current revenues & 14.1 & 14.0 & 14.7 & 19.3 & 23.4 & 22.6 \\
\hline GDP at market prices (EC\$ millions) & 933 & 987 & 1,025 & 1,091 & 1,161 & 1,156 \\
\hline
\end{tabular}

Sources: Ministry of Finance and Planning; and Fund staff estimates and projections.

1/ As in the approved budget, except for capital expenditures, for which an execution rate of 50 percent is assumed, in line with the average rate for 2001-04.

current account deficit in 2004 was driven by: a decline in exports, and a general rise in imports, especially of energy products, food, equipment, and building materials largely related to private housing and tourism-related investment. In 2005 the current account is expected to continue to deteriorate (to about 28 percent of GDP), mainly on account of higher imports due to additional public capital expenditure and rising oil import costs, St. Vincent and the Grenadines: Selected External Indicators, 2000-2005 notwithstanding a rebound in banana export earnings.

\section{External}

competitiveness has improved in recent years (Figure 2). The

\begin{tabular}{lcccccc}
\hline & 2000 & 2001 & 2002 & 2003 & $\begin{array}{c}2004 \\
\text { Est. }\end{array}$ & $\begin{array}{c}2005 \\
\text { Proj. }\end{array}$ \\
\hline & & & & & & \\
& (Percentage change) & & & & & \\
Terms of trade & & & & & & \\
Real effective exchange rate, (depreciation -) & -3.3 & 2.9 & 2.1 & -4.2 & -3.4 & -3.2 \\
Banana export receipts & 5.1 & 0.5 & -6.7 & -8.3 & -5.0 &.. \\
& -10.2 & -25.4 & 16.0 & -24.2 & 8.7 & 7.7 \\
& (In percent of GDP) & & & & & \\
Current account & -6.8 & -10.5 & -11.3 & -19.9 & -25.5 & -27.6 \\
Exports & 53.5 & 50.9 & 48.8 & 45.5 & 43.3 & 44.0 \\
Imports & 59.7 & 60.2 & 58.5 & 62.5 & 66.2 & 69.0 \\
Tourism receipts & 24.5 & 25.8 & 24.9 & 24.0 & 23.7 & 22.6 \\
& & & & & & \\
Foreign direct investment (net) & 11.3 & 6.1 & 10.2 & 14.5 & 13.8 & 12.1 \\
Outstanding external debt (end of period) & 47.8 & 49.1 & 46.5 & 51.3 & 54.7 & 56.4 \\
\hline
\end{tabular}

Sources: St. Vincent and Grenadines authorities, ECCB, and Fund staff estimates.

depreciation of the U.S. dollar against major currencies since 2002 (by 18 percent in real effective terms) has improved competitiveness in European tourism markets. Increases in wage levels have been modest (including relative to other ECCU countries), in part due to a civil service wage freeze during 2002 and 2003, although the number of civil servants has increased considerably. Current account imbalances continue to be largely financed by FDI flows. 
Figure 2. St. Vincent and Grenadines: External Competitiveness, 1990-2004

While the CPI-based real effective exchange rate has depreciated sharply since 2002 ...

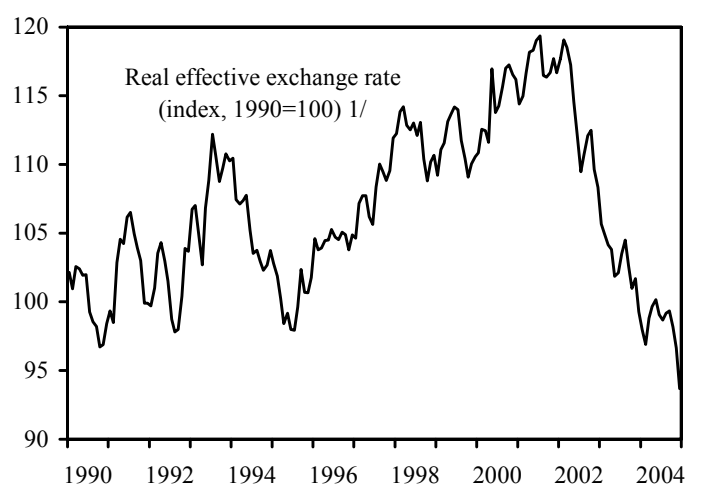

Overall exports have weakened dramatically after growing rapidly during the early 1990 s...

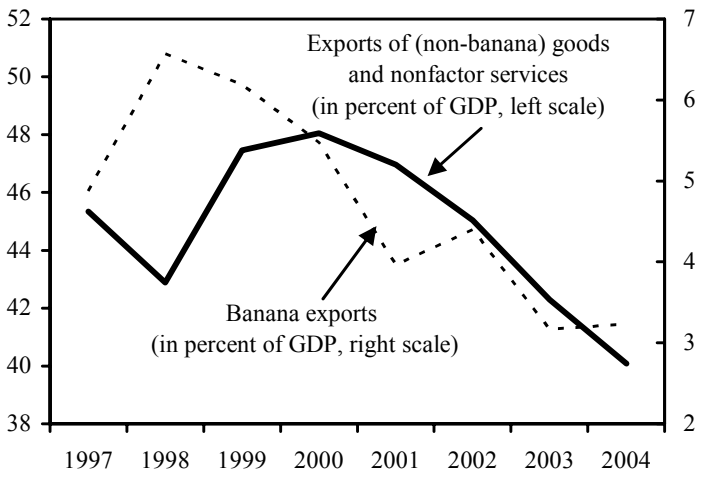

In the tourism sector, the competitor and customerbased measures of the REER have depreciated ..

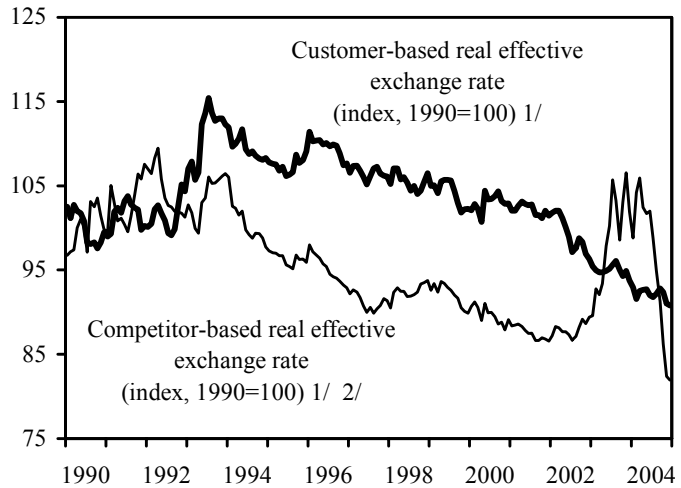

...private and public sector real wages and numbers of civil servants have grown.

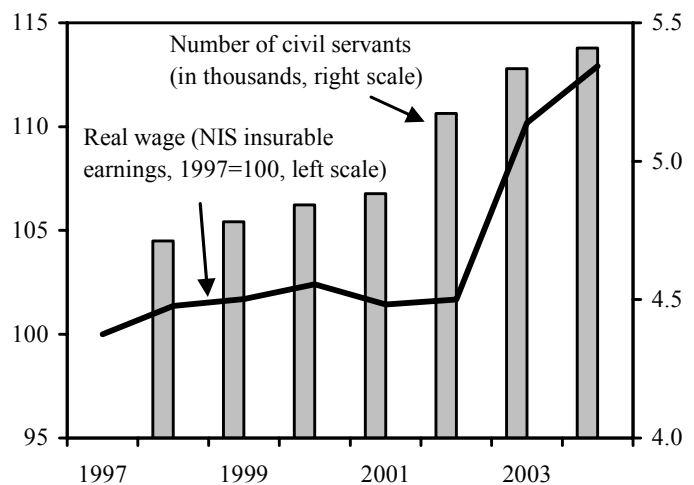

...while overseas development assistance flows have continued their steady decline since the early 1990 s.

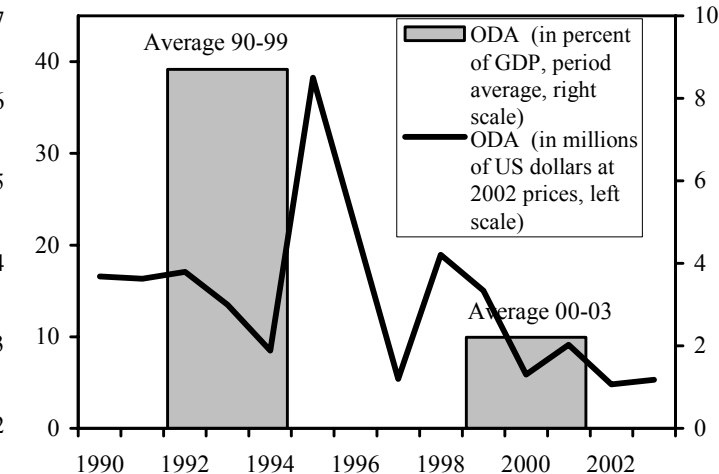

...while St. Vincent's share of stay-over arrivals in both the ECCU and the Caribbean has increased since 1998.

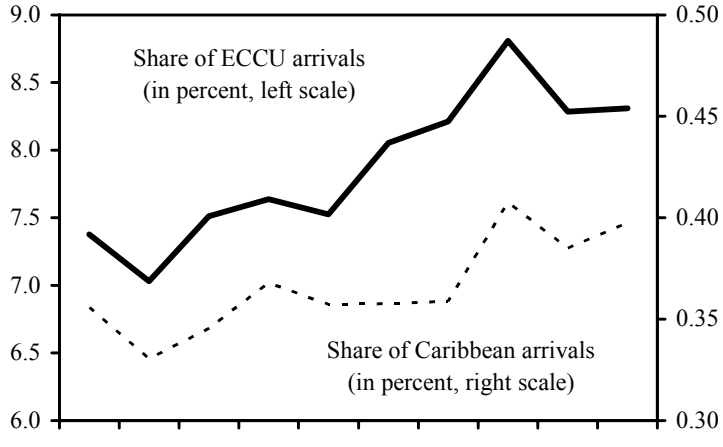

1995199619971998199920002001200220032004

Sources: ECCB, Caribbean Tourism Organization, St. Vincent and the Grenadines authorities, and Fund staff calculations

$1 /$ An increase (decrease) indicates an appreciation (depreciation).

2/ The sharp movements in the competitor-based real exchange rate in 2002-04 were largely driven by the Dominican Republic's peso. 


\section{Box 1. St. Vincent and the Grenadines: Summary of Approved 2005 Budget}

The budget envisages a large increase in the budget deficit (overall balance) from 3.4 percent of GDP in 2004 to $61 / 2$ percent of GDP in 2005. This is mainly due to a jump in expenditures of over $4 \frac{1}{2}$ percent of GDP to 38.3 percent of GDP, while revenues and grants are expected to increase only modestly, by about 1 percent of GDP to 31.8 percent of GDP. The public debt-to-GDP ratio would rise to about 84 percent of GDP.

\section{Tax measures}

Budgeted revenue measures are relatively modest in strength, yielding about $0.5-0.7$ percent of GDP. The main new tax measures are:

- A tax on all calls made on cellular telephones at the rate of 5 percent. This is expected to yield about 0.2 percent of GDP in 2005 .

- An increase in the retail price of petroleum products: an increase in the gasoline price of 50 cents (6.7 percent) to EC\$8 per gallon; and an increase in the diesel price of 75 cents (12.5 percent) to EC\$6.75 per gallon. This will entail additional revenues amounting to about $0.2-0.4$ percent of GDP in 2005 .

- A 10 percent tax on lottery winnings in excess of EC\$500. The yield for this measure is expected to be 0.1 percent of GDP.

\section{Expenditure measures}

The government is planning to substantially increase its expenditure outlays across the board. Current expenditures are expected to increase by 18 percent to 29.3 percent of GDP, while capital expenditures would increase by 30 percent to 8.9 percent of GDP. Most of the envisaged increase in current expenditures emanates from wages and salaries (1.1 percent of GDP), mainly due to an increase in the number of civil servants, as well as a contracted salary increase of 3 percent in 2005 . The main new expenditure items include:

- Universal secondary education: the full cost is unclear but the program is expected to entail an additional 0.3 percent of GDP for new school facilities, and the hiring of 90 new teachers.

- Continuation of the low-income housing project: 350 new houses are expected to be completed in 2005.

- $\quad$ Construction of the Windward Highway and Cross-Country road, estimated to cost at least 0.7 percent of GDP in 2005 .

- Construction of Canouan jetport, entailing 21/2 percent of GDP in additional expenditures per year over two years.

- Increase of 0.1 percent of GDP in subsidies to banana producers.

- Contribution to the recapitalization of the regional airline, LIAT, costing 0.5 percent of GDP, financed through an interest-free loan from the Government of Trinidad and Tobago. 


\section{Consistent with growth in economic activity, monetary liabilities and domestic} credit have rebounded. Broad money (M2) growth accelerated in 2004, as deposits (particularly savings deposits) with the banking sector rose strongly. While net lending to the central government continued to decline in 2004 (with the government actually holding net deposits for the first time), credit to the private sector rose marginally. Net foreign assets of the banking system surged, as both commercial banks' net foreign assets and St. Vincent and the Grenadines' implicit reserves at the ECCB increased substantially. In 2005 , credit to private sector is

St. Vincent and the Grenadines: Selected Monetary Indicators, 2000-05

\begin{tabular}{lllllll}
\hline 2000 & 2001 & 2002 & 2003 & $\begin{array}{c}2004 \\
\text { Est. }\end{array}$ & $\begin{array}{c}2005 \\
\text { Proj. }\end{array}$ \\
\hline
\end{tabular}

(Annual percentage change)

\begin{tabular}{|c|c|c|c|c|c|c|}
\hline Broad money & 9.5 & 3.0 & 8.3 & 1.9 & 12.4 & 6.0 \\
\hline Credit to private sector & 8.5 & 2.3 & 4.6 & 0.6 & 0.2 & 2.6 \\
\hline \multicolumn{7}{|c|}{ (Percent contribution to growth in broad money) } \\
\hline Net foreign assets & 11.2 & -4.1 & 2.9 & 5.7 & 16.0 & 3.9 \\
\hline Net domestic assets & -1.7 & 7.2 & 5.4 & -3.9 & -3.6 & 2.1 \\
\hline $\begin{array}{l}\text { Net credit to public sector } \\
\text { Of which: }\end{array}$ & 1.9 & 0.3 & 4.8 & -4.0 & 3.3 & 2.0 \\
\hline Central government & 1.1 & -2.9 & 6.4 & -5.5 & -7.2 & 4.5 \\
\hline Credit to private sector & 8.0 & 2.1 & 4.3 & 0.6 & 0.2 & 2.0 \\
\hline Net credit to nonbank financial inst. & 1.2 & -3.5 & 0.9 & -0.3 & 2.9 & -0.7 \\
\hline Other assets (net) & -12.8 & 8.3 & -4.6 & -0.2 & -10.0 & -1.3 \\
\hline
\end{tabular}
projected to increase in line with anticipated growth in the service sector. Net credit to the central government is projected to increase due to government draw down on disbursed borrowed funds, as well as the capital needs associated with several large infrastructure projects commencing in 2005.

12. Prudential indicators point to weaknesses in the banking sector, although efforts are ongoing to strengthen bank balance sheets (Figure 3). Total capital-to-risk-weighted assets of indigenous (locally incorporated) banks are considerably below the ECCU average, while indigenous banks also have a large portfolio of nonperforming loans. Public sector exposures are high, especially for local banks. Both the National Commercial Bank (NCB), the country's largest indigenous bank, and the Development Bank have sold nonperforming loans to an asset Banking Sector: Selected Financial Soundness Indicators, December 2004 (In percent)

\begin{tabular}{lcc}
\hline & $\begin{array}{c}\text { St. Vincent } \\
\text { \& the Grens. }\end{array}$ & $\begin{array}{c}\text { ECCU } \\
\text { Average }\end{array}$ \\
\hline Capital adequacy ratio 1/ & 8.9 & 17.3 \\
Unsatisfactory assets/total loans & 9.6 & 12.0 \\
Gross government exposure/total assets & 20.7 & 15.3 \\
Provisions for loan losses/total loans & 3.3 & 4.1 \\
Provisions for loan losses/unsatisfactory assets & 34.3 & 34.3 \\
(Pre-tax) return on average equity (domestic banks) & 1.3 & 13.9 \\
(Pre-tax) return on average assets & 1.2 & 1.8 \\
\hline
\end{tabular}

Source: ECCB.

1/ Total qualifying capital/risk weighted assets (domestically licensed banks). recovery company. While this disposal has lowered the stock of nonperforming loans, bank profitability has suffered. ${ }^{3}$

\footnotetext{
${ }^{3}$ The NCB did not experience a significant rise in its NPL ratio following Hurricane Ivan, yet the NPL ratio did increase significantly following the September 11, 2001 terrorist attacks, due to the decline in tourist arrivals.
} 
Figure 3. St. Vincent and the Grenadines: Banking System Developments, 1998-2004 (In percent)

Since 2001, both lending and deposit rates have fallen, but spreads have remained broadly unchanged.

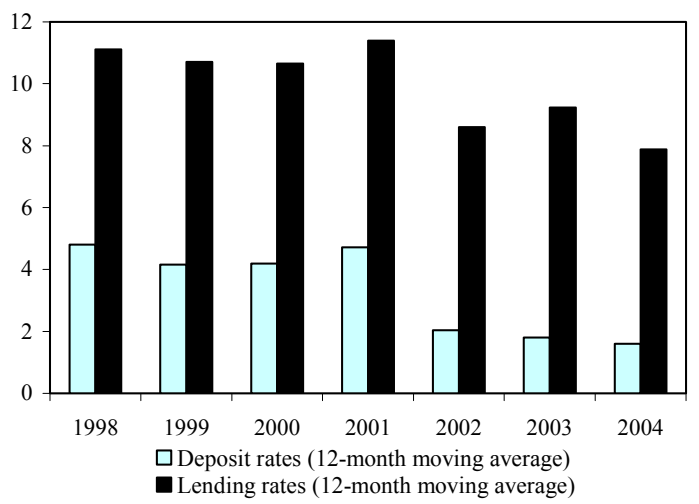

Household loans dominate the lending portfolio (both for foreign and local banks).

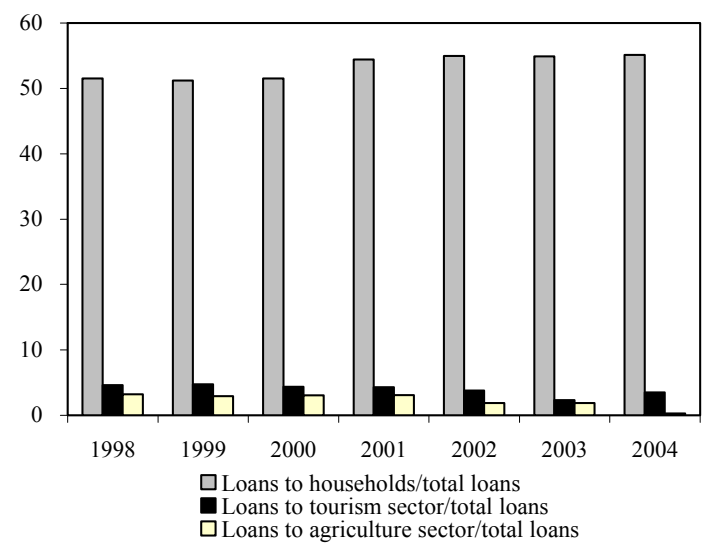

Government exposures and government deposits are higher for local banks, rendering the banking system vulnerable to impairment of government obligations.

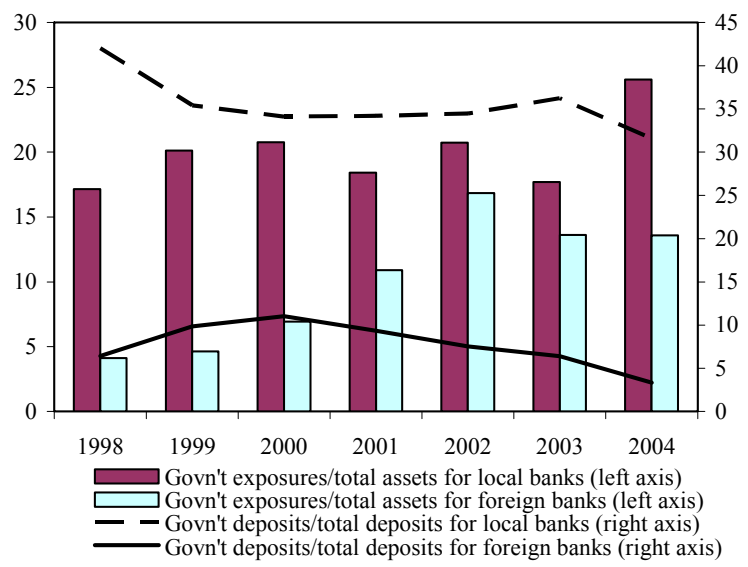

Bank profitability has been declining for local banks since 2002, while foreign banks have steadily increased profitability since 2000 .

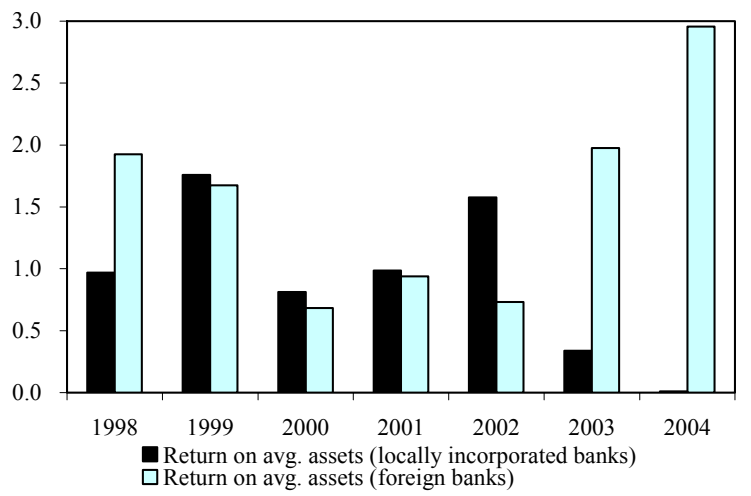

Nonperforming loans remain considerably higher for local banks than foreign banks, while provisioning is lower.

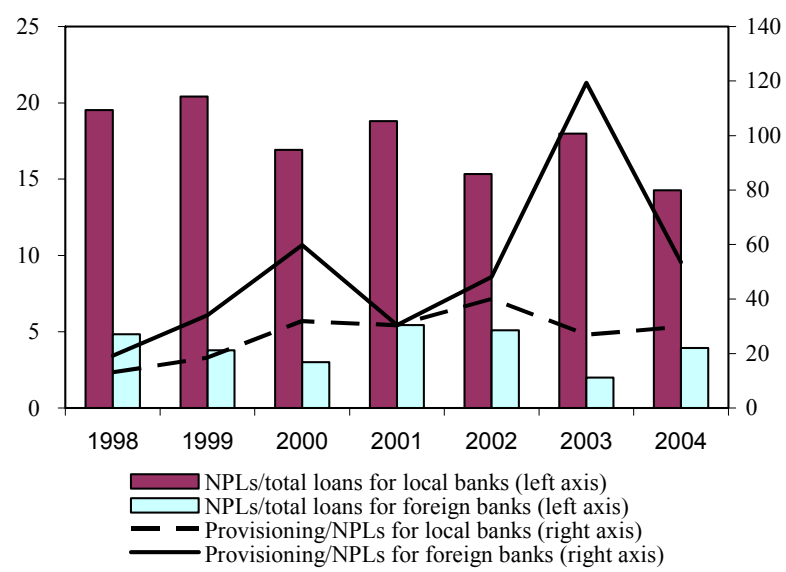

Capital adequacy ratios are declining for local banks, while bank liquidity remains high.

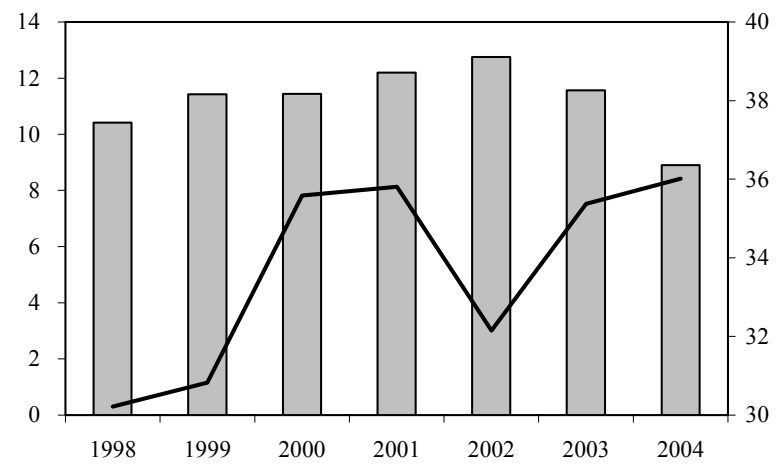

Total capital as share of risk-weighted assets, local banks (left axis) —Liquid assets/total assets (right axis)

Sources: ECCB, St. Vincent and the Grenadines authorities. 
13. Despite its rising stock of debt, St. Vincent and the Grenadines has been able to borrow from the Regional Government Securities Market (RGSM) at declining spreads over U.S. treasury bills. Financing short-term needs through this market has reduced the cost of public borrowings, while the issuance of long-dated bonds has helped increase the availability of inexpensive and reliable financing.
St. Vincent and the Grenadines: Interest Rate, 91-Day Treasury Bills, 2003-05 (In percent)

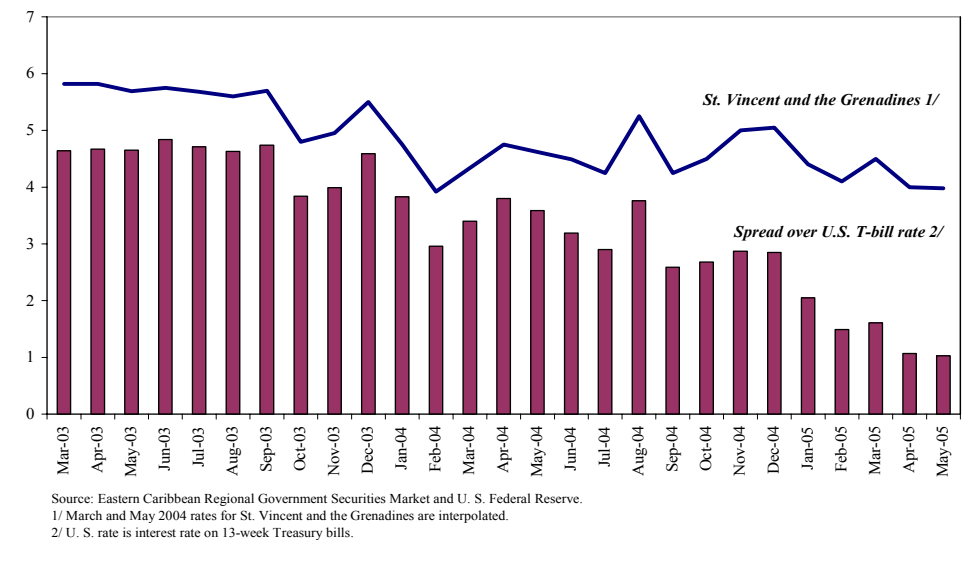

14. Some progress has been made in structural reforms. The restructuring of the banana industry has continued with European Union support, and the authorities continue in their efforts to diversify production (under the Agricultural Diversification Program) into non-banana agriculture. Progress has been made in raising domestic prices of energy inputs and in tax administration, and in efforts to improve labor skills through training programs. The authorities have restated their intention to introduce a VAT and market valuation-based property taxation in 2007, as recommended by the OECS Tax Reform and Administration Commission. A one-stop shop for foreign investment enquiries and facilitation has been created with the establishment of the National Investment Promotions Incorporated (NIPI). Efforts have also been made to monitor and reduce the operational losses of public enterprises, through the establishment of a Monitoring Committee on Public Enterprises, headed by the Prime Minister.

\section{REPORT ON THE DISCUSSIONS}

\section{A. Overview}

15. The growth potential of the economy needs to be raised and public debt reduced to alleviate poverty and bring St. Vincent and the Grenadines' income level closer to that of its ECCU counterparts. Staff emphasized that the economic rebound in 2004-05 provides an opportunity to reduce St. Vincent and the Grenadines' growing debt burden. Reducing public debt will provide fiscal room for maneuver in the event of adverse exogenous shocks, allow for an expansion of private sector activity, and release resources for social sector spending. Accordingly, the discussions were organized around three key areas:

- $\quad$ raising medium-term growth potential, including enhancing regional cooperation, expanding remittance and investment flows from the large diaspora, and addressing structural change in the economy; 
- $\quad$ ensuring debt sustainability and reinforcing fiscal policy, through a combination of measures to foster fiscal consolidation and prioritization of the ambitious public investment program; and

- $\quad$ reducing vulnerabilities to adverse shocks, in particular, natural disasters and potential contagion from national and regional banking crises.

16. The authorities broadly agreed with the mission's recommendations and its assessment of the major issues confronting the economy. The authorities welcomed the heightened focus during this consultation on enhancing growth, reducing vulnerabilities to shocks, and the broader regional perspective drawn from the Fund's ECCU Regional Discussions. They argued that a key policy challenge was ensuring structural transformation of the economy while at the same time controlling debt levels and the cost of debt servicing.

17. The dialogue between Fund staff and the authorities has deepened. The authorities considered the mission's recommendations useful, and conveyed their particular appreciation for the provision of detailed fiscal policy recommendations, as was provided during the October 2004 staff visit and the Article IV consultation. The government has been receptive to Fund advice in its budget deliberations on raising revenues, and has taken further steps to bolster revenues in the context of the 2005 budget in line with staff recommendations. However, the government has not been as responsive with regard to expenditure control, as the authorities have felt that such expenditures are justified to address considerable infrastructure weaknesses and to meet important social goals, such as poverty reduction and universal secondary education. CARTAC's technical assistance continues to be used effectively in improving national accounts compilation, taxation administration, and offshore banking supervision.

\section{B. Enhancing Growth Potential and Alleviating Poverty}

18. The transition of the economy from agriculture toward more valued-added services will raise the economy's growth potential and assist in poverty reduction. Achieving success with this strategy will require reforms across a broad spectrum. In the absence of such reforms, growth can be expected to stagnate at about $2 \frac{1}{2}$ percent per year, given the growing debt burden and accompanying fiscal drag. While economic growth in St. Vincent and the Grenadines has slowed significantly since the late 1980s, near-term growth prospects appear quite strong - trend growth under the active scenario is assumed to be about 4 percent per year. For their part, the authorities considered the staff's view of medium-term growth prospects overly cautious - they argued that growth could average about 5-6 percent per year, given success in the economy's transition into tourism and 
diversification of its agriculture sector. ${ }^{4}$ The mission recommended that reforms to enhance growth potential should focus on:

- Enhancing valued added from tourism. The tourism sector is the dominant source of foreign exchange and employment in the country, with services constituting about 73 percent of GDP in 2004. Staff encouraged the authorities to examine the extent to which vertical diversification (into niche tourism markets), market diversification (tapping nontraditional tourism-customer markets), and enhancing linkages between the local agriculture and tourism (with the former dominated by the low-income, rural component of the labor force) can boost value added from the tourism sector. While concurring with the mission, the authorities expressed the view that in order to significantly boost the long-term potential for tourism, there is need to enhance air transport linkages and infrastructure. ${ }^{5}$ It is in this light that the authorities argued that it is necessary to build the Canouan Island jetport (at a cost of at least US\$20 million).

- $\quad$ Strengthening the investment climate. Staff argued that there is need to further improve the investment climate, but that increasing tax concessions is not an optimal strategy. In common with most OECS countries, extensive concessions have been granted to stimulate investment and promote job creation. However, discretionary concessions severely distort competition between enterprises. The mission welcomed the creation of National Investment Promotions Inc., with the goal of streamlining bureaucracy and reducing the cost of doing business, as a step in the right direction.

- $\quad$ Better leveraging benefits from migration. More than a quarter of the country's labor force has emigrated to the OECD in the period 1970-2000, with disproportionately heavy losses (in excess of half) among the highly

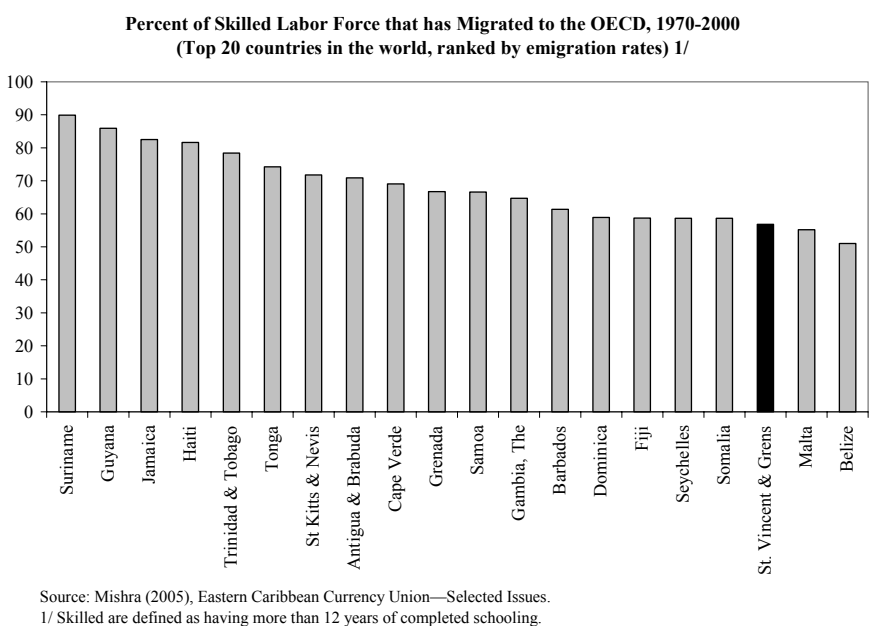

\footnotetext{
${ }^{4}$ The authorities continue in their endeavors to promote economic diversification through: the Agriculture Diversification Program, enhancing links between agriculture and tourism, developing the fishing industry, and greater food processing.

${ }^{5}$ Currently, the country does not have an international airport which allows access for medium-haul jet aircraft.
} 
educated ${ }^{6}$. This large-scale emigration has produced a steady flow of remittances from Vincentians abroad. The authorities and the staff agreed that greater use could be made of the country's large diaspora to build networks for trade, investment promotion and tourism, in order to reduce the net costs of emigration (given the provision of free primary and secondary education).

- Regional integration and cooperation. The small size of local markets often precludes industries in ECCU countries from achieving economies of scale. Moreover, there is much less intra-ECCU movement of labor than of goods, services and capital. In this connection, the mission argued that the authorities need to assess the potential benefits from enhancing regional integration through efforts to: provide government services collectively; attain greater flexibility in the movement of goods, services and factors, particularly labor, across the borders of ECCU countries; and enhance regional arrangements that would facilitate greater integration with the world economy. The authorities stated that they were keen to participate fully in the Caribbean Single Market and Economy (CSME), and would welcome the free movement of labor within CSME-member countries. In this vein, they have passed legislation to liberalize the movement of skilled persons (Skilled Nationals Act), including by allowing national social security benefits to be carried over by OECS nationals, and movement for business activities (National Factors Act).

- Banana industry. The erosion of trade preferences for banana exports has imposed near-term pressures on St. Vincent and the Grenadines (Annex I). Banana producers are facing an uncertain future (given the expected conversion of EU quotas into tariffs in 2006), as free market prices are considerably below the level of those available in protected EU markets. Staff recommended that the authorities use the

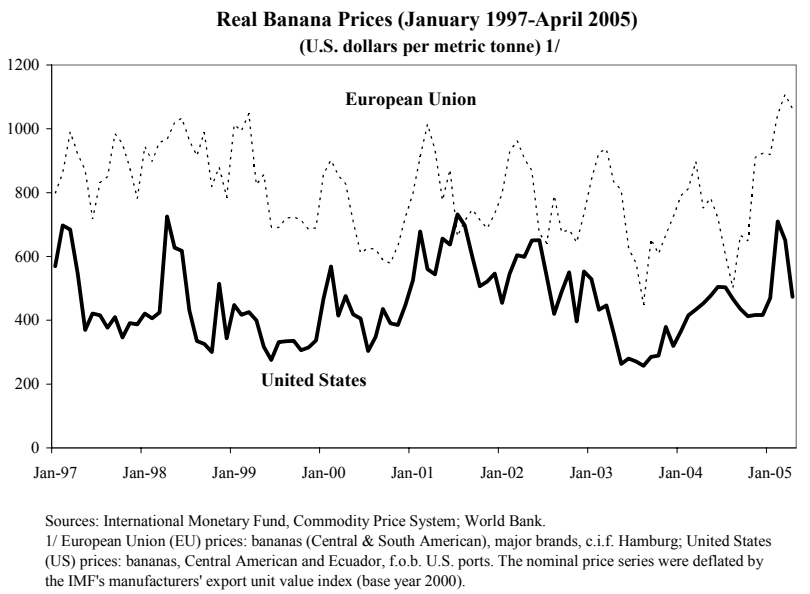
period prior to the removal of trade preferences to smooth the economic transition by enhancing social safety nets for displaced farmers and agricultural workers. To limit the social impact of the transition, staff would support the temporary use of fiscal measures - such as income transfers to farmers, the provision of noncontributory

\footnotetext{
${ }^{6}$ The final report of the 2001 national population and housing census shows that the population size has stagnated since 1991, registering a small decline of 0.2 percent to 106,253. Apart from lower birth rates, the main reason for this decline is emigration.
} 
pensions, retraining programs and

limited subsidies on agricultural inputs - designed to support

affected populations, and

encourage economic

diversification. $^{7}$

19. Sustained economic growth is the key to improving living standards and alleviating poverty. In consultation with civil society, and under the leadership of the National Economic and

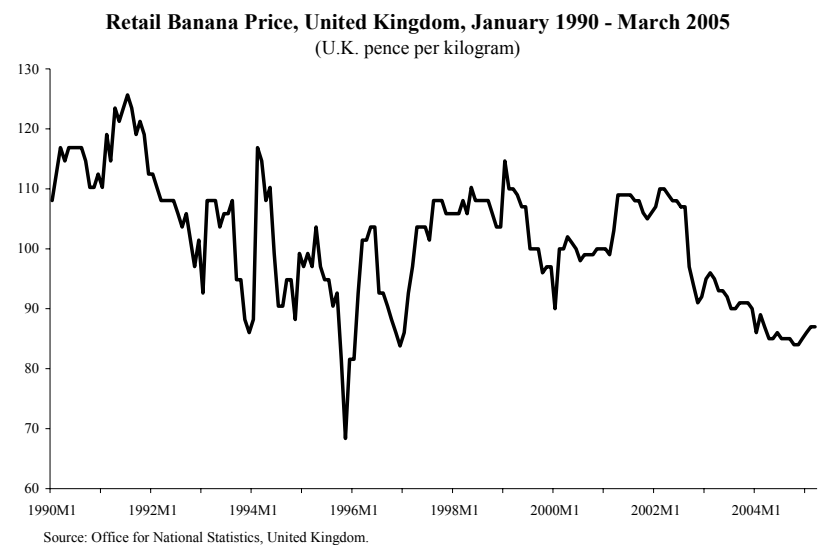
Social Development Council (NESDC), the government has been guided in its povertyreduction efforts by the home-developed Interim-Poverty Reduction Strategy (I-PRSP). The I-PRSP identifies national priorities for poverty reduction, and will inform the allocation of donor-provided funds designed to reduce poverty (Box 2). Staff commended the authorities for these efforts, and for the incorporation of guidelines for economic development and poverty reduction as part of the Social Contract with trade unions, the private sector, and civil society.

\section{Debt Sustainability and Fiscal Policy}

\section{The staff recognized the authorities' intentions to strike a balance between providing fiscal stimulus and ensuring debt sustainability. In the recent past the} government has used its capital program as a means of stimulating economic activity at a time of below-average national economic growth, while simultaneously seeking to control the deterioration in the overall balance by dampening growth in current expenditure and enhancing its revenue-raising activities. In this regard, the recently adopted Fiscal Covenant sets out the government's views on striking a balance between fiscal stimulus and debt sustainability, the institutional structure of fiscal policymaking, and improvements to the transparency and productivity of public expenditure. ${ }^{8}$ However, the mission pointed out that this counter-cyclical fiscal stance had worsened fiscal imbalances since 2000 and fueled a

\footnotetext{
${ }^{7}$ While the long-term trend is for rising consumption of bananas on European markets, price competition by U.K. retailers (the dominant market for Windward Islands bananas) has seen retail banana prices fall sharply, particularly since late 2002. This challenging market for bananas will place additional competitive pressures on Caribbean producers, irrespective of the eventual form and level of trade preferences.

${ }^{8}$ The Covenant has five basic components: (i) consolidating fiscal adjustment; (ii) raising the productivity of public sector expenditure; (iii) increasing fiscal transparency; (iv) promoting social equity; and (v) promoting the development of democratic institutions. The only specified quantitative target in the Covenant is that current expenditure should not exceed 85 percent of current revenues.
} 
rapid increase in public indebtedness, with the debt-to-GDP ratio climbing by 12 percentage points of GDP (to 79 percent) in the period 2000-04.

21. The mission argued that as economic growth continues to accelerate from its recent lows, there is less need for a high level of public investment to stimulate economic activity. Staff argued that the government should not allow an asymmetry in their counter-cyclical fiscal policy, by failing to wind down its capital spending program as the pace of domestic economic activity quickens.

\section{A continuation of current fiscal policies would lead to an unsustainable level of} debt, and crowd-out expenditure on the achievement of important social and economic goals. According to staff projections, debt will decline only gradually over the medium term, even in the presence of strong fiscal adjustment and good growth performance. Most of the alternative scenarios and bound tests in the debt sustainability analyses show that without the adjustment envisaged in the active scenario, debt levels would either continue to rise over time or decline only marginally. Under current policies, the stock of debt will reach over 95 percent of GDP by the end of the decade, and likely higher if adjustment is not frontloaded. As a consequence, central government interest payments would rise to 5 percent of GDP (one-sixth of current revenues), increasing the government's vulnerability to debt rollover risk and reducing its ability to undertake expenditures in achieving other important goals, such as poverty alleviation. While not contesting staff analysis, the authorities argued that a short-term expansion in the stock of public debt was necessary, to ensure long-term sustainable growth. In this regard, they pointed to their plans to curb capital expenditure from 2007.

23. The mission argued that placing debt on a clear downward path will require the sustained implementation of a strong set of policy reforms. Such a set of reforms would involve a mixture of growth-enhancing structural measures; fiscal consolidation; and a reinforcement of the authorities' debt management strategy. Under the active scenario, involving additional fiscal measures (yielding about $2 \frac{1}{2}$ percent of GDP in 2005) and medium-term growth rising to about 4 percent per year, staff projections suggest the debt stock will decline to about 64 percent of GDP over the next six years. The fiscal adjustment could be achieved by: the introduction of a broadbased consumption tax and market-

St. Vincent and the Grenadines: Public Sector Debt Dynamics (In percent of GDP)
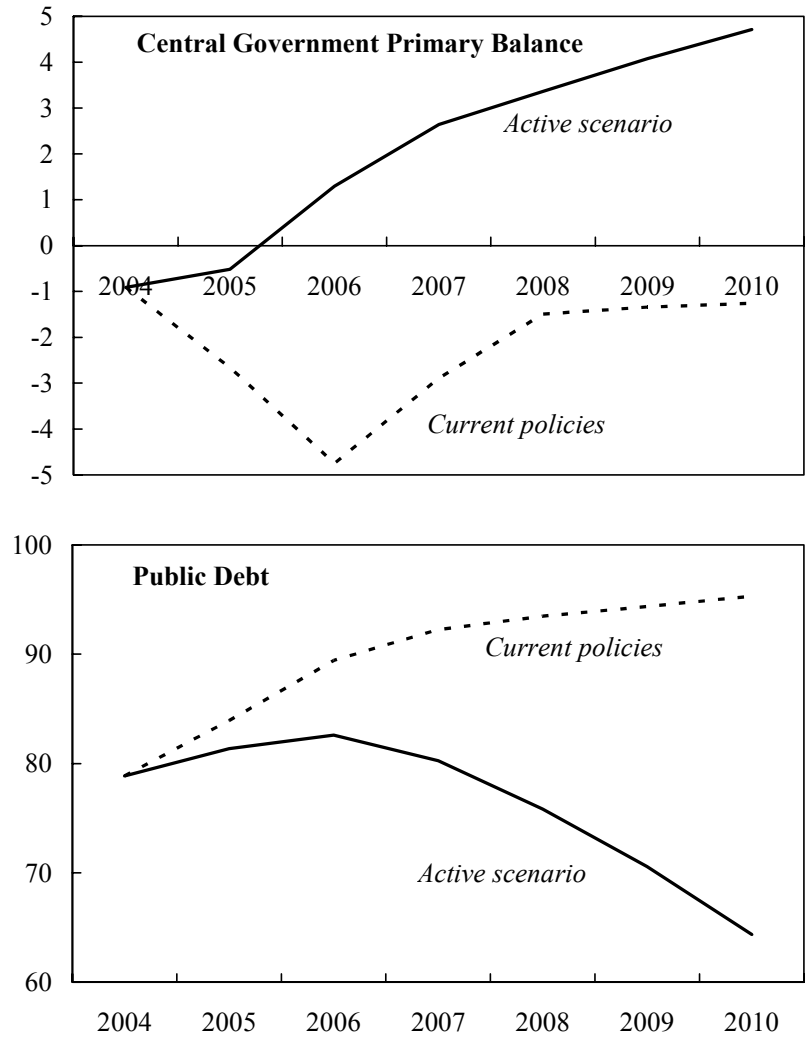
valuation based property tax; holding the wage bill constant in real terms through civil service reforms; maintaining expenditure on goods and services and transfers constant as a proportion of GDP; and reducing capital expenditure to about 7 percent of GDP (see Annex II).

\section{Box 2. St. Vincent and the Grenadines: Poverty Indicators and Poverty Reduction Strategy}

The process of developing a poverty reduction strategy began in September 2001, under the new government. The government assigned responsibility for the development of a Poverty Reduction Framework to the National Economic and Social Development Council (NESDC), which comprises representatives from the government ministries, the ECCB and other financial institutions, private sector, and civil society groups. A Poverty Reduction Task Force was established by the NESDC to develop the Poverty Reduction Strategy. The final revision of the Interim Poverty Reduction Strategy Paper (I-PRSP) was completed in June 2003.

Timely and comprehensive poverty data for St. Vincent and the Grenadines are fairly limited. The most recent source of statistical data on the incidence of poverty in St. Vincent and the Grenadines is "The Poverty Assessment Report" prepared by a group of consultants in 1996 . The report states that $371 / 2$ percent of the population (30.6 percent of households) is poor (defined as income below the locally-defined poverty line), of which 25.7 percent of the population (20.4 percent of households) is indigent. A study prepared in 2001 on "The Socio-Economic Impact of Restructuring the Banana Industry" indicates a worsening of the poverty situation as a result of severe shocks to the economy since 1995.

The strategy for poverty reduction adopted by the government follows a multi-faceted approach, and includes: (i) a job creation program (including the Youth Empowerment Service to address youth unemployment); (ii) a low-income housing project; (iii) an enhanced safety net for the poor through public assistance; (iv) the promotion of a micro-enterprise sector; (v) increased subsidies to banana farmers; and (vi) large new infrastructure projects in roads, airports and power plants.

In order to promote civil society participation in national policy formulation the NESDC has developed a "Social Contract". The contract aims at fixing the general framework for cooperation between government and civil society in both policy formulation and monitoring.

Data from the 2001 Population and Housing Census provides some information on living standards in St. Vincent and the Grenadines. Census data reveals that the unemployment rate was 21.1 percent, compared with 19.8 percent in 1991. In the 2001 Census, about 90 percent of Vincentian households owned stoves, 66 percent had refrigerators, 53 percent had a telephone, while about 15 percent owned washing machines.

Optimal debt stock and debt concessionality

24. Preliminary calculations by staff indicate that the external public debt of St. Vincent and the Grenadines is only marginally concessional. In the past the authorities have argued that - using a 10 percent discount rate- - their debt was highly concessional and 
therefore nominal debt-to-GDP indicators were not particularly useful for St. Vincent and the Grenadines. Using a 5 percent as discount rate, the debt is not highly concessional, as the grant element is only about 7 percent. ${ }^{9}$ Accordingly, the staff pointed out that while during the 1980s and early 1990s there may have been a large concessional component of external borrowings, a number of changes in the structure of debt - notably the rapid accumulation of commercial debt in the $2000 \mathrm{~s}$ - has meant that the country's overall debt profile is no longer concessional.

25. The mission commended the government for its recent efforts to develop a Debt Strategy (as part of the Fiscal Covenant), but argued that the strategy needs to be strengthened. The mission stated that the authorities' medium-term public debt target of 75 percent of GDP is too high, given the growing cost of debt servicing which in 2005 will consume 23 percent of current revenues, the declining concessionality of public borrowings, and the high volatility of national income and export receipts. The authorities argued that this medium-term debt target was achievable and would set a useful benchmark by which to guide fiscal policy. The authorities also noted that an important component of the Debt Strategy has been their continuing discussions with Ottley Hall creditors, in attempting to reach agreement on a restructuring of obligations.

\section{Revenue measures}

26. The scope for increasing tax rates-already high in St. Vincent and the Grenadines-is relatively limited, but there is some room for raising revenues by broadening the coverage of the tax system. Key aspects of this broadening of the tax base over the medium term include:

- $\quad$ Value added tax. The authorities have committed to the introduction of a VAT in 2007, and have established a VAT implementation unit. Staff urged authorities to begin the process of introducing the VAT, since it requires a substantial preparatory period - at least 18 months to 2 years - to successfully introduce such a tax. ${ }^{10}$

- $\quad$ Property tax. The real estate sector appears to be performing well, but with little improvement in property tax collections. The authorities have committed to the introduction of a market valuation-based property tax in 2006-07. Staff encouraged

\footnotetext{
${ }^{9}$ A more appropriate way to determine concessionality would be to use currency-specific commercial interest reference rates (CIRRs). In the absence of loan-by-loan details, the discount rate of 5 percent is likely close to the weighted average of the discount rates of the currencies in the basket of external loans held by the country (comprising 75 percent U.S. dollar and U.S. dollar-linked loans, 81/2 percent in SDRs and the remainder in other currencies).

${ }^{10}$ As recommended by the staff, the authorities have requested technical assistance from CARTAC in the design and implementation of the VAT.
} 
the government to undertake the required cadastral surveys and introduce such a property tax system as soon as technically feasible.

- $\quad$ Tax concessions. There is a need to significantly enhance control over the granting of tax concessions. Concessions are a major source of revenue loss, with concessions on international trade taxes representing about one third of tax revenues gathered in 2004. The mission recommended that the overall level of statutory concessions should be reduced,

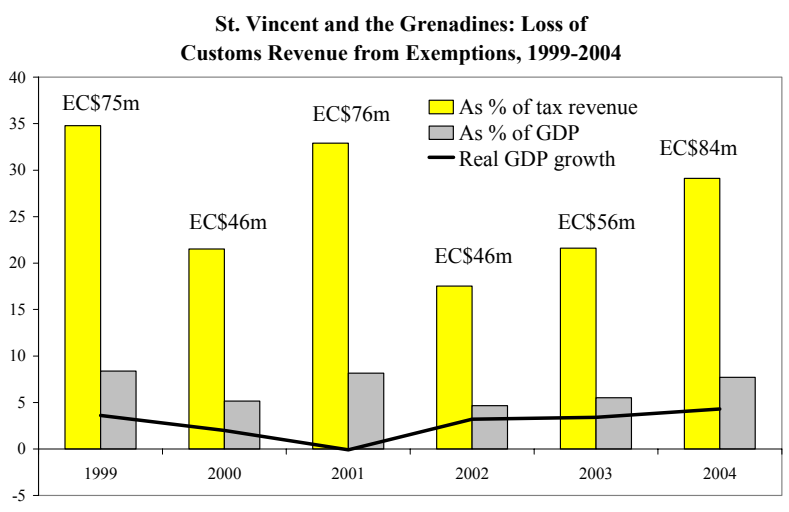

Source: St. Vincent and the Grenadines, Customs and Excise Department. and that the scope for concessions should be strictly limited to those in the statutes. In view of the fact that other ECCU countries have similar concessions, the authorities were urged to seek greater regional cooperation, in order to have a common approach to tax concessions, and thereby avoid a "race to the bottom." While the authorities were in broad agreement with the mission's recommendations to rein in concessions, they argued that given the strong competition between Caribbean jurisdictions for foreign investment, some level of concessions would need to remain.

- $\quad$ Taxation of petroleum products. The mission noted that retail prices of petroleum products are among the lowest in the ECCU region. Recent rises in global oil prices have significantly dampened revenues earned from petroleum taxation. The mission recommended that taxation of petroleum products should be improved in order to make the yield more predictable, and for prices ECCU: Retail Gasoline Prices, end-May 2005 to reflect the true economic cost. At present, the government is continuing to absorb any additional cost of higher world oil prices in order to peg the retail price of fuel. Although retail prices were raised in August 2004 and January 2005, staff believes that retail prices

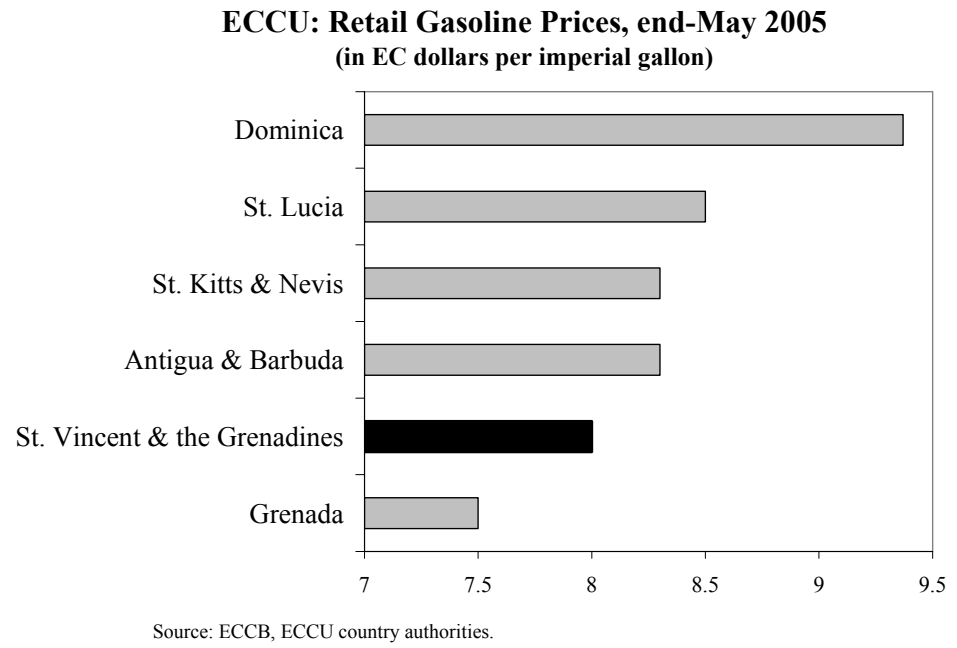
should be adjusted through an automatic mechanism, so as to ensure that the authorities garner the full amount of the legislated consumption tax as world (and landed) petroleum prices 
change. The authorities agreed that the current regime is leading to the erosion of tax revenues, but noted the need to move carefully in raising the retail price of petroleum. They argued that increasing prices would adversely affect vulnerable groups, by raising the cost of public transportation and fuel for cooking. The staff responded that it would fully support targeted expenditure on the provision of social safety nets for such vulnerable groups.

\section{Expenditure measures}

27. On the expenditure side, the potential for consolidation of spending is high. The mission argued that expenditures need to be strictly contained, and the implementation of a number of new initiatives delayed. In particular, the staff noted that there is a clear need to significantly scale back expenditures relative to those in the approved 2005 budget. Staff recommended adoption of measures to yield 2 $\frac{1}{2}$ percent of GDP in 2005 . The main areas of expenditure reduction include: maintaining wages and salaries constant in real terms (yielding savings of 0.9 percent of GDP); maintaining transfers constant in nominal terms (0.7 percent of GDP); lower interest payments on the smaller stock of debt $(0.3$ percent of GDP); and reducing capital spending to well-targeted projects ( 0.7 percent of GDP). Expenditure measures should focus on near-term rationalizations, and on a gradual diminution of the size of the public sector. Key recommendations included:

- $\quad$ Public sector wages and employment. Efforts should focus on increasing the costeffectiveness of service provision by raising productivity in the civil service. The wage bill remains large relative to other ECCU: Wage Bill of Central Government, 2000-04 expenditure items and also in comparison to other small island economies both within and outside the region. There is scope to reduce overall public employment as the private sector increasingly drives growth in the economy, thereby providing room

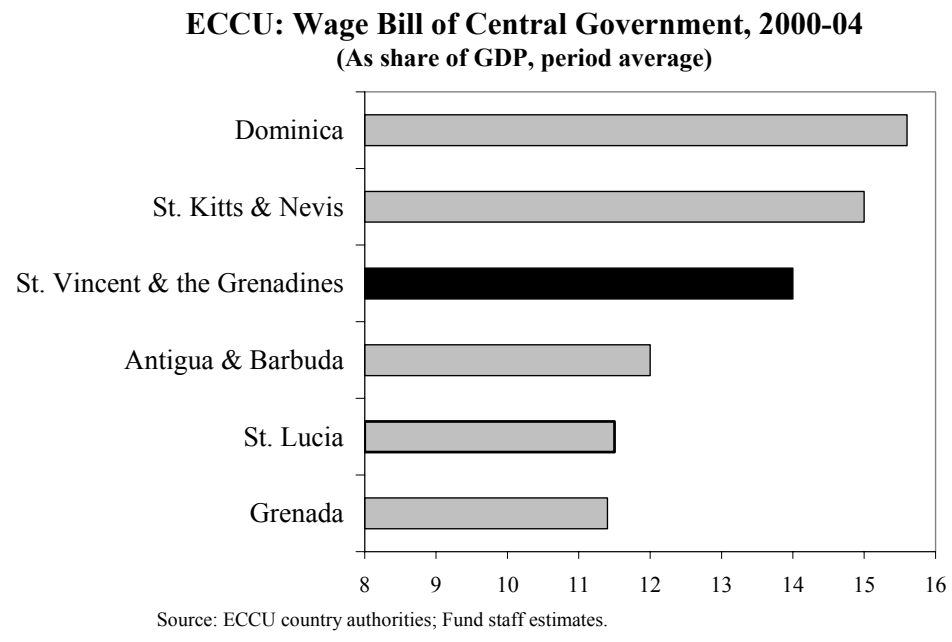
for wage increases (in line with productivity) while keeping the wage bill constant. ${ }^{11}$ The authorities argued that given the multi-island composition of the country, there

\footnotetext{
${ }^{11}$ Public sector wages were unchanged in 2002 and 2003; in 2004 and 2005 wages rose by 4 and 3 percent, respectively.
} 
was a need to replicate the provision of public services across islands, which entailed greater numbers of civil servants.

- $\quad$ Capital expenditures. The level of expenditures has gradually risen since 2001 to over 8 percent of GDP - higher than the 1995-2000 average of $6 \frac{1}{2}$ percent of GDP. Tighter control and prioritization over the execution of capital projects could generate significant savings over the medium term. The government should give greater emphasis not to the volume of capital expenditure, but to the efficiency of such spending. To this end, a careful review of the contents of the PSIP to ensure that it emphasizes projects with a high rate of return and avoids unproductive projects, particularly those financed on nonconcessional terms, is required.

\section{Reducing Vulnerabilities}

\section{St. Vincent and the Grenadines' high vulnerability to natural disasters}

\section{underscores the need for} disaster-preparedness initiatives to cope with these shocks. Ten major disasters have hit the country since 1970, making it the world's most disaster-affected nation. The government has recently prepared a National Disaster Response Plan, which includes plans for managing contingencies related to hurricanes, volcanic eruptions and floods. The staff welcomes this initiative, as well as the enhancements to the National Emergency Management Office. Introduction and implementation of the draft National Building Code should also reduce the vulnerability of the housing stock to natural hazards. Notwith-standing these measures, staff recommended that the authorities place additional emphasis on disaster mitigation and preparedness. Insurance of government assets could also be improved, as at present only a
St. Vincent and the Grenadines: Exogenous Shocks and Real GDP Growth (1980-2004)

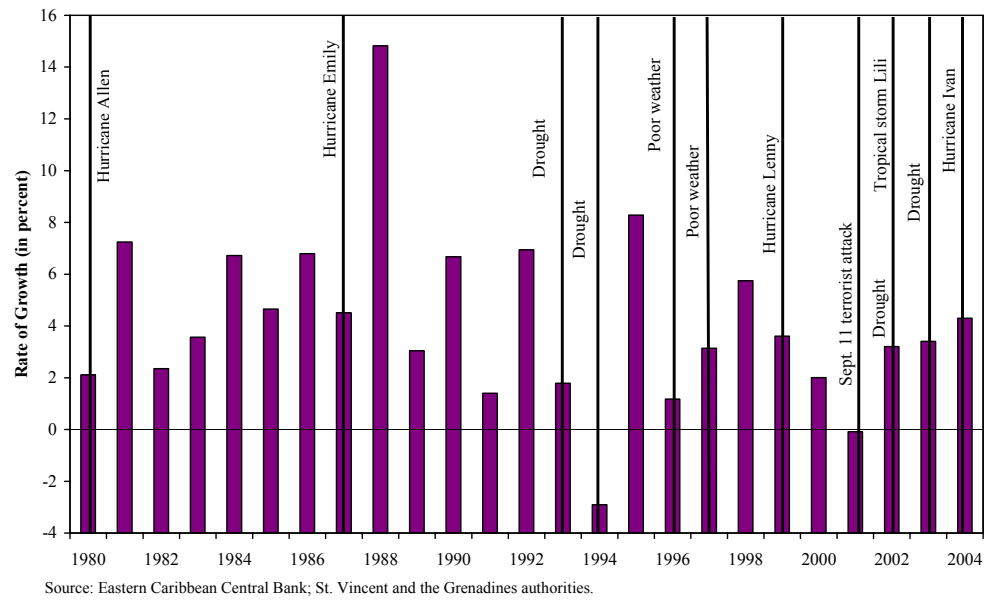

Eastern Caribbean Currency Union: Incidence of Natural Disasters Compared to the Rest of the World, 1970-2002

\begin{tabular}{|c|c|c|c|c|c|}
\hline & \multicolumn{5}{|c|}{ All Recorded Disasters } \\
\hline & \multirow{2}{*}{$\begin{array}{l}\text { Number } \\
\text { of Events }\end{array}$} & \multicolumn{2}{|c|}{$\begin{array}{c}\text { Number of Events } \\
\text { Divided by } \\
\text { Land Area }\end{array}$} & \multicolumn{2}{|c|}{$\begin{array}{c}\text { Number of Event } \\
\text { Divided by } \\
\text { Population }\end{array}$} \\
\hline & & Index & Rank & Index & Rank \\
\hline All countries & 6,480 & 100 & 76 & 100 & 76 \\
\hline Advanced economies & 1,511 & 23 & 70 & 39 & 91 \\
\hline Caribbean & 162 & 599 & 23 & 387 & 23 \\
\hline ECCU6 & 44 & 1,212 & 5 & 770 & 6 \\
\hline Antigua and Barbuda & 7 & 1,198 & 3 & 883 & 4 \\
\hline Dominica & 8 & 803 & 8 & 890 & 3 \\
\hline Grenada & 4 & 886 & 7 & 348 & 12 \\
\hline St. Kitts and Nevis & 7 & 1,465 & 2 & 1,295 & 2 \\
\hline St. Lucia & 8 & 988 & 6 & 451 & 8 \\
\hline St. Vincent and Grenadines & 10 & 1,931 & 1 & 755 & 6 \\
\hline Other Caribbean & 118 & 190 & 36 & 131 & 35 \\
\hline Other & 4,807 & 49 & 84 & 75 & 79 \\
\hline
\end{tabular}

Sources: EM-DAT for data on natural disasters; World Bank, World Development Indicators for data on land area; IMF, World Economic Outlook database for data on population.

Note: The sample contains 150 countries after omitting countries without at least one natural disaster associated with a cost estimate and/or missing information on GDP (24 advanced economies, 15 Caribbean countries, and 111 other developing countries). Simple unweighted averages are used for country groupings. Rankings are in descending order, with "1" indicating the most exposed to natural disaster. 
small fraction of public buildings and assets are insured. Staff also encouraged the authorities to participate in regional initiatives (such as those of the World Bank) designed to pool insurance risk across countries, and thereby lower the cost of catastrophic insurance.

29. Potential vulnerabilities in the financial sector appear concentrated in the stateowned National Commercial Bank (NCB), which accounts for about one quarter of financial system assets. As with most regional indigenous banks, the NCB is highly exposed to the local public sector, ${ }^{12}$ and has a large (albeit declining) portfolio of nonperforming loans (Figure 3). The NCB is currently drawing on external management expertise and technical assistance in efforts to restructure its operations, enhance efficiencies and raise profitability.

\section{Financial soundness indicators and stress testing results suggest that locally} incorporated banks (which account for about 60 percent of total banking system assets) are weak and vulnerable to adverse shocks that impair government obligations and interrupt tourism. ${ }^{13}$ While locally-incorporated banks appear sufficiently capitalized (with an 8.9 percent aggregate capital adequacy ratio at end-2004), due to the absence of riskweighting on government exposures and potential under-provisioning, local banks' true capital position may be lower. Foreign bank branches generally have lower rates of nonperforming loans, and are well provisioned. Cross-border linkages are relatively low, thereby reducing vulnerability to regional shocks - holdings of other ECCU public sector claims and net claims on other ECCU banks amount to $3 \frac{1}{2}$ and $81 / 2$ percent of banks' assets, respectively. The ECCB's external reserve coverage stands at 96 percent of monetary demand liabilities, substantially in excess of the legal floor of 60 percent. ${ }^{14}$ Nonetheless, due to the quasi-currency board arrangement, there is limited room for the ECCB to act as a lender of last resort.

\section{Further strengthening the prudential and regulatory framework would reduce} vulnerabilities in the financial sector. The 2004 ECCU regional FSAP report identified a number of weaknesses in the supervisory and regulatory framework for both banks and nonbank financial institutions. Approval of the proposed amendments to the Uniform Banking Act would be an important step in this regard, by helping to foster a strong financial system capable of supporting growth, and address many of the weaknesses identified in the 2004 regional FSAP. While nonbank financial institutions - credit unions, the building

\footnotetext{
${ }^{12}$ Commercial banks' exposure to government amounts to about one-fifth of total assets (see Figure 3).

${ }^{13}$ Exceptional but plausible stress scenarios for St. Vincent and the Grenadines include a major natural disaster that entails significant economic losses and a sharp decline in tourism arrivals. It is assumed that such a scenario could lead to a nonrepayment of 10 percent of banks' government exposures and an increase of 5 percent of total loans in loan losses. Under this scenario, all the locally-incorporated banks would be technically insolvent, as their capital would be below the Basel prudential guidelines.

${ }^{14} \mathrm{St}$. Vincent and the Grenadines' (imputed) reserve coverage of short-term liabilities is high, amounting to over 400 percent at end-2004.
} 
society, the insurance sector, and the Development Bank - are smaller in size, staff urged the authorities to continue to strengthen their regulatory and supervisory framework. The Report on the Observance of Standards and Codes (ROSC) of 2004 identified a need to further enhance the regulatory and supervisory framework for the offshore banking sectorincluding the introduction of a risk-based framework for capital adequacy and implementation of prudential requirements. ${ }^{15}$ The International Bank Act, adopted in December 2004, strengthens the supervision of the country's offshore sector. Operational prudential guidelines consistent with the Basel Core Principles have been drafted, but not yet issued.

\section{E. Statistical Issues}

32. As the structure of the economy changes, there is a need to ensure that the statistical database provides relevant, accurate and timely information to policymakers. The mission encouraged the authorities to strengthen the coverage of the national accounts, especially for the tourism and services sector. There remain substantial weaknesses in data on the labor market, domestic and external debt, tourism arrivals and expenditure, the nonbank financial sector, foreign project aid, and on the financial activities of the public enterprises. Staff urge the authorities to devote more resources to collection and dissemination of data in these areas. Staff also encourages the authorities to strengthen the central statistical office, in particular by continuing to make recourse to technical assistance offered through CARTAC.

\section{Staff Appraisal}

33. Economic prospects have brightened since the nadir of 2001, aided by sustained activity in construction and a favorable external environment. The tourism sector has expanded rapidly with the increase in stay-over arrivals during 2004. Prospects for further expansion in the sector, including tourism-related services and associated construction activity, appear strong and are likely to underpin growth for the next several years.

34. However, the level of public debt has increased significantly over the past year. The government borrowed heavily during the last quarter of 2004, in anticipation of forthcoming projects. The outlook for 2005 is quite difficult as without additional expenditure restraint the overall deficit is likely to reach $6 \frac{1}{2}$ percent of GDP, an unprecedented level in St. Vincent and the Grenadines. Staff therefore strongly urges the

\footnotetext{
15 St. Vincent and the Grenadines was removed from the FATF list of noncooperating territories in June 2003, following an upgrading of its supervisory and regulatory framework. Activity in the offshore sector rebounded strongly in 2004. As of April 2005, the St. Vincent and the Grenadines' offshore sector comprised: seven offshore banks, 6,328 international business companies, 129 international trusts, 12 international insurance companies, and 26 mutual funds - all are regulated by the International Finance Service Authority.
} 
government to address the weakening fiscal situation by implementing the recommended measures to reduce the deficit.

35. In the absence of a strong effort to tackle the growing fiscal imbalances, the cost of debt servicing will increase, and the stock of debt could be placed on an unsustainable path. Even with an acceleration in growth accompanied by a large and sustained fiscal adjustment, the debt burden will shrink only gradually over the medium term. Such a high debt level heightens the risk from adverse shocks, and acts to constrain the government's future ability to engage in counter-cyclical policy. Staff therefore recommends that the government significantly strengthen its debt strategy, and pay close attention to the level of debt (including the nominal debt-to-GDP ratio) as a useful indicator of the debt burden, as well as address the composition of debt by reducing the share of commercial debt.

36. Staff welcomes the government's plans to improve tax policy and administration, and emphasizes the need to broaden the tax base and reduce concessions. The planned adoption of the VAT and market-based property taxation are steps in the right direction. However, more needs to be done, particularly in the area of tax concessions. Discretionary tax concessions should be removed, while the overall level of statutory concessions should be reduced, and the scope for concessions should be strictly limited to those in the statutes. Staff urges the authorities to seek greater regional cooperation, in order to have a common approach to tax concessions, and thereby avoid a region-wide "race to the bottom."

37. There is a need to control the wage bill, which has increased rapidly due to continued recruitment despite a stagnant national population. A wide-ranging civil service reform is urgently needed to ensure that expenditure consolidation can be achieved without impinging on the quality of service provision. At the same time, the high level of capital expenditure is likely inefficient and unsustainable - the authorities are thus urged to undertake a prioritization (and cost-benefit analysis) of proposed public investment projects.

38. St. Vincent and the Grenadines is among the most disaster-prone countries in the world. The authorities have made great strides in boosting their disaster mitigation and preparedness, through the drafting of a national disaster plan, and tightening building codes. However, the mission recommends that the authorities undertake greater efforts to transfer disaster risk, particularly through regional insurance pools and enhanced insurance of public buildings and infrastructure assets.

39. The financial sector remains vulnerable to adverse shocks. The government should urgently present to Parliament amendments to the Uniform Banking Act, which would significantly strengthen prudential supervision. In particular, the authorities should give the ECCB licensing authority for banks under the new Act. Given the systemic importance of the state-owned National Commercial Bank, the government is encouraged to continue its efforts to address management and asset quality weaknesses. The large holding of public sector debt by domestic banks renders the banking system vulnerable to uncertainty as to the sustainability of public sector imbalances. To avoid a further build-up of financial 
sector vulnerability as nonbank financial intermediaries grow in importance, staff recommends that the authorities establish a broad supervisory framework to regulate all nonbank financial intermediaries (including insurance companies, credit unions and other near banks). The authorities' efforts to enhance supervision of the offshore sector are welcomed, and should be continued to ensure the consistency of the regulatory and supervisory frameworks with international best practices.

40. St. Vincent and the Grenadines' statistical data remains weak in terms of coverage, timeliness and frequency, and major improvements in all areas are needed to facilitate policymaking and effective surveillance. Improvements are particularly needed in the coverage of the national accounts (especially the tourism sector and related services), and on data used to monitor labor market developments. In addition, while in areas central to surveillance, notably central government accounts, financial sector indicators, and external sector accounts, the data is of adequate quality for surveillance purposes, the data quality for the rest of the public sector is quite poor, and obtained with considerable lags.

41. Staff welcomes the government's efforts at increasing opportunities for discussion of public policy, especially through the formation of National Economic and Social Development Council. The home-grown I-PRSP encapsulates the desire of the government to build a public consensus behind the key objective of reducing poverty, and the need for greater transparency. The authorities are commended for hosting the International Banana Conference (in June 2004) as a means to consider policy options for the industry. Increased efforts to disseminate and explain economic developments and policy choices would also deepen the understanding of, and support for, structural reforms.

42. It is recommended that the next Article IV consultation take place on the standard 12-month cycle. 
Table 1. St. Vincent and the Grenadines: Selected Social and Economic Indicators, 2000-2005

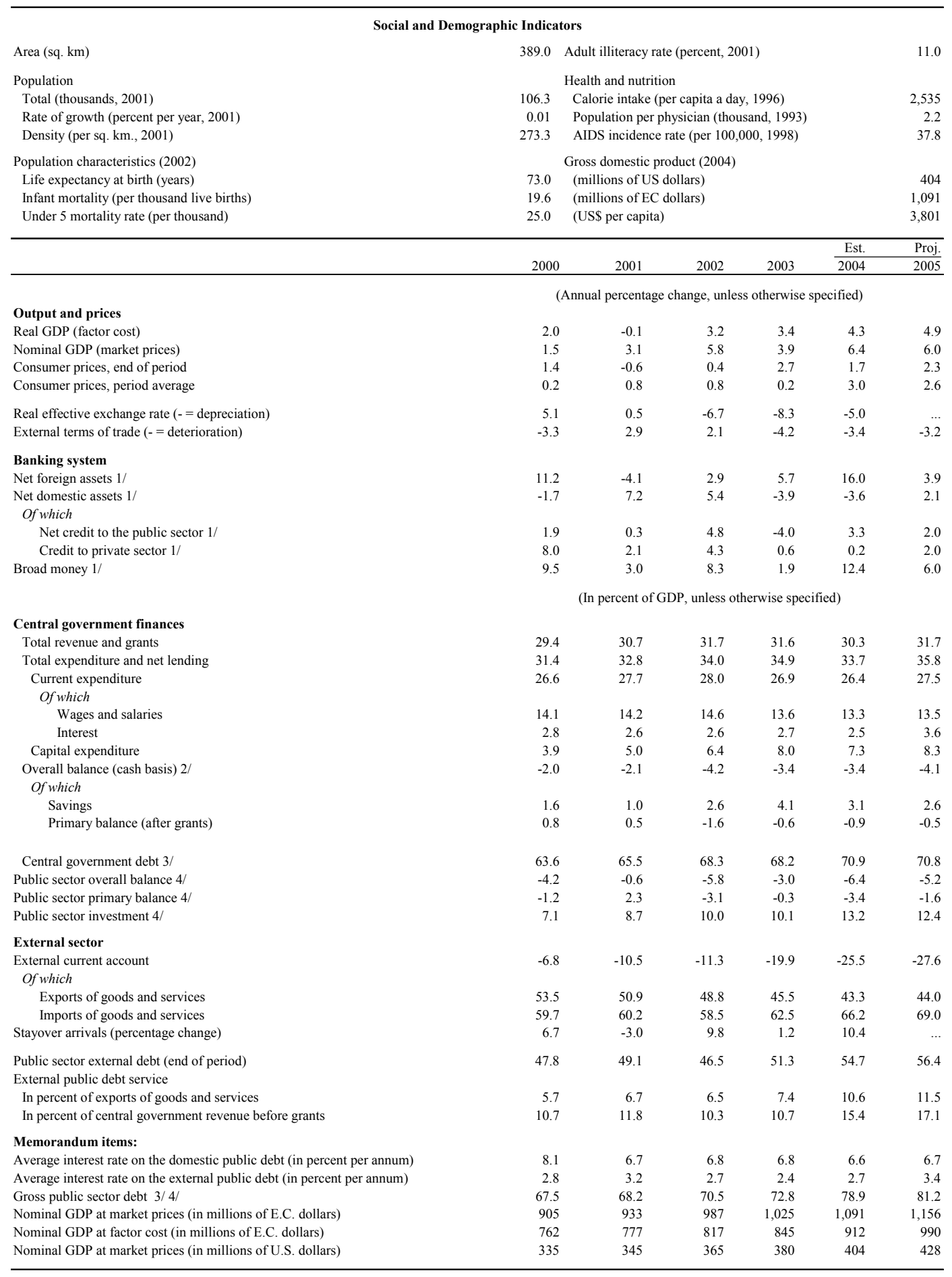

Sources: Eastern Caribbean Central Bank, Ministry of Finance and Planning; Banana Growers' Association, and Fund staff estimates and projections.

1/ Annual changes relative to the stock of broad money at the beginning of the period.

2/ Includes the difference between the overall balance as measured from above the line and from below the line (i.e. financing), which may include float and unidentified discrepancies.

3/ Net of intra-public sector debt (mainly central government debt to the NIS).

4/ The consolidated public sector includes the central government, the National Insurance Scheme (NIS), Kingstown Board, and 10 nonfinancial public enterprises. 


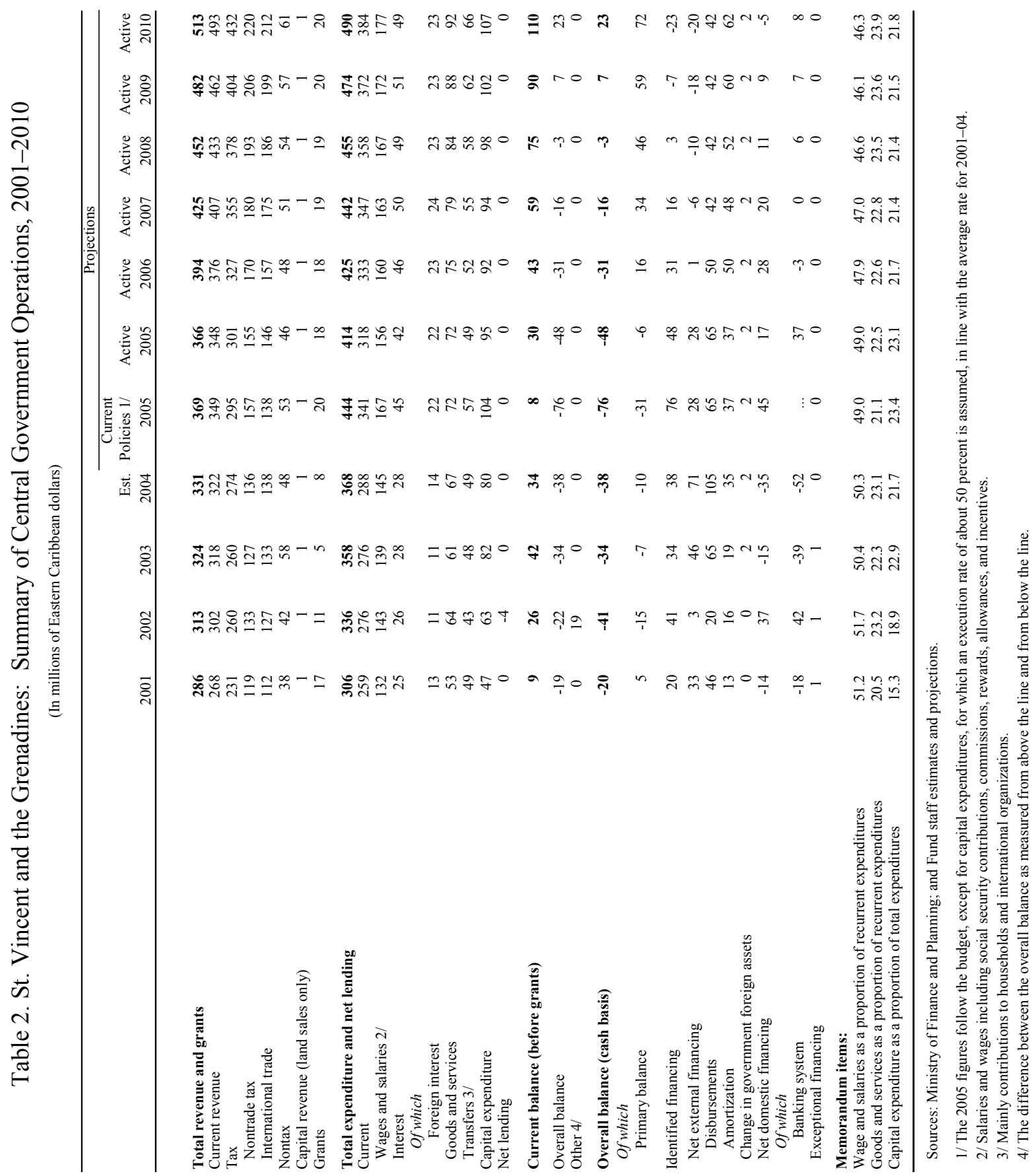


Table 3. St. Vincent and the Grenadines: Summary of Central Government Operations, 2001-2010 (In percent of GDP)

\begin{tabular}{|c|c|c|c|c|c|c|c|c|c|c|c|}
\hline & \multirow[b]{4}{*}{2001} & \multirow[b]{4}{*}{2002} & \multirow[b]{4}{*}{2003} & \multicolumn{8}{|c|}{ Projections } \\
\hline & & & & \multirow{3}{*}{$\begin{array}{r}\text { Est. } \\
2004 \\
\end{array}$} & \multirow{3}{*}{$\begin{array}{r}\text { Current } \\
\text { Policies 1/ } \\
2005 \\
\end{array}$} & \multirow{3}{*}{$\begin{array}{r}\text { Active } \\
2005\end{array}$} & \multirow{3}{*}{$\begin{array}{r}\text { Active } \\
2006\end{array}$} & \multirow{3}{*}{$\begin{array}{r}\text { Active } \\
2007\end{array}$} & \multirow{3}{*}{$\begin{array}{r}\text { Active } \\
2008 \\
\end{array}$} & \multirow{3}{*}{$\begin{array}{r}\text { Active } \\
2009\end{array}$} & \multirow{3}{*}{$\begin{array}{r}\text { Active } \\
2010\end{array}$} \\
\hline & & & & & & & & & & & \\
\hline & & & & & & & & & & & \\
\hline Total revenue and grants & 30.7 & 31.7 & 31.6 & 30.3 & 31.8 & 31.7 & 32.6 & 33.3 & 33.4 & 33.5 & 33.6 \\
\hline Current revenue & 28.7 & 30.6 & 31.0 & 29.5 & 30.0 & 30.1 & 31.0 & 31.8 & 31.9 & 32.1 & 32.3 \\
\hline Tax & 24.7 & 26.3 & 25.3 & 25.1 & 25.4 & 26.1 & 27.0 & 27.8 & 27.9 & 28.1 & 28.3 \\
\hline Nontrade tax & 12.7 & 13.5 & 12.4 & 12.5 & 13.5 & 13.4 & 14.0 & 14.1 & 14.2 & 14.3 & 14.4 \\
\hline International trade & 12.0 & 12.8 & 13.0 & 12.7 & 11.9 & 12.6 & 13.0 & 13.7 & 13.7 & 13.8 & 13.9 \\
\hline Nontax & 4.0 & 4.3 & 5.7 & 4.4 & 4.6 & 4.0 & 4.0 & 4.0 & 4.0 & 4.0 & 4.0 \\
\hline Capital revenue (land sales only) & 0.1 & 0.1 & 0.1 & 0.1 & 0.1 & 0.1 & 0.1 & 0.1 & 0.1 & 0.1 & 0.1 \\
\hline Grants & 1.9 & 1.1 & 0.4 & 0.7 & 1.7 & 1.6 & 1.5 & 1.5 & 1.4 & 1.4 & 1.3 \\
\hline Total expenditure and net lending & 32.8 & 34.0 & 34.9 & 33.7 & 38.3 & 35.8 & 35.1 & 34.6 & 33.6 & 33.0 & 32.2 \\
\hline Current & 27.7 & 28.0 & 26.9 & 26.4 & 29.3 & 27.5 & 27.5 & 27.2 & 26.4 & 25.9 & 25.2 \\
\hline Wages and salaries 2/ & 14.2 & 14.5 & 13.6 & 13.3 & 14.4 & 13.5 & 13.2 & 12.8 & 12.3 & 11.9 & 11.6 \\
\hline Interest & 2.6 & 2.6 & 2.7 & 2.5 & 3.9 & 3.6 & 3.8 & 3.9 & 3.6 & 3.6 & 3.2 \\
\hline \multicolumn{12}{|l|}{ Of which } \\
\hline Foreign interest & 1.3 & 1.1 & 1.1 & 1.3 & 1.9 & 1.9 & 1.9 & 1.9 & 1.7 & 1.6 & 1.5 \\
\hline Goods and services & 5.7 & 6.5 & 6.0 & 6.1 & 6.2 & 6.2 & 6.2 & 6.2 & 6.2 & 6.1 & 6.0 \\
\hline Transfers $3 /$ & 5.2 & 4.4 & 4.6 & 4.5 & 4.9 & 4.2 & 4.3 & 4.3 & 4.3 & 4.3 & 4.3 \\
\hline Capital expenditure & 5.0 & 6.4 & 8.0 & 7.3 & 8.9 & 8.3 & 7.6 & 7.4 & 7.2 & 7.1 & 7.0 \\
\hline Net lending & 0.0 & -0.4 & 0.0 & 0.0 & 0.0 & 0.0 & 0.0 & 0.0 & 0.0 & 0.0 & 0.0 \\
\hline Current balance (before grants) & 1.0 & 2.6 & 4.1 & 3.1 & 0.7 & 2.6 & 3.6 & 4.6 & 5.6 & 6.3 & 7.2 \\
\hline Overall balance (above the line) & -2.1 & -2.3 & -3.4 & -3.4 & -6.5 & -4.1 & -2.5 & -1.3 & -0.2 & 0.5 & 1.5 \\
\hline Other 4/ & 0.0 & 1.9 & 0.0 & 0.0 & 0.0 & 0.0 & 0.0 & 0.0 & 0.0 & 0.0 & 0.0 \\
\hline Overall balance (cash basis) & -2.1 & -4.2 & -3.4 & -3.4 & -6.5 & -4.1 & -2.5 & -1.3 & -0.2 & 0.5 & 1.5 \\
\hline \multicolumn{12}{|l|}{ Of which } \\
\hline Primary balance & 0.5 & -1.6 & -0.6 & -0.9 & -2.7 & -0.5 & 1.3 & 2.6 & 3.4 & 4.1 & 4.7 \\
\hline Identified financing & 2.1 & 4.2 & 3.4 & 3.4 & 6.5 & 4.1 & 2.5 & 1.4 & 0.4 & -0.3 & -1.2 \\
\hline Net external financing & 3.5 & 0.3 & 4.5 & 6.5 & 2.4 & 2.4 & 0.0 & -0.5 & -0.7 & -1.3 & -1.3 \\
\hline Disbursements & 4.9 & 2.0 & 6.4 & 9.7 & 5.6 & 5.6 & 4.1 & 3.3 & 3.1 & 2.9 & 2.8 \\
\hline Amortization & 1.4 & 1.6 & 1.8 & 3.2 & 3.2 & 3.2 & 4.1 & 3.8 & 3.8 & 4.2 & 4.0 \\
\hline Change in government foreign assets & 0.0 & 0.0 & 0.2 & 0.2 & 0.2 & 0.2 & 0.2 & 0.2 & 0.3 & 0.4 & 0.4 \\
\hline Net domestic financing & -1.5 & 3.7 & -1.5 & -3.2 & 3.9 & 1.5 & 2.3 & 1.6 & 0.8 & 0.6 & -0.3 \\
\hline \multicolumn{12}{|l|}{ Of which } \\
\hline Banking system & -1.9 & 4.3 & -3.8 & -4.8 & $\ldots$ & 3.2 & -0.2 & 0.0 & 0.4 & 0.5 & 0.5 \\
\hline Exceptional financing & 0.1 & 0.1 & 0.1 & 0.0 & 0.0 & 0.0 & 0.0 & 0.0 & 0.0 & 0.0 & 0.0 \\
\hline \multicolumn{12}{|l|}{ Memorandum items: } \\
\hline Gross central government debt (in percent of GDP) & 65.5 & 68.3 & 68.2 & 70.9 & 73.1 & 70.8 & 69.9 & 67.5 & 63.6 & 59.4 & 55.8 \\
\hline Public sector debt (in percent of GDP) $5 /$ & 68.2 & 70.5 & 72.8 & 78.9 & 83.9 & 81.3 & 82.6 & 80.2 & 75.8 & 70.6 & 64.4 \\
\hline Debt service as a proportion of current revenues $6 /$ & 14.1 & 14.0 & 14.7 & 19.3 & 23.4 & 22.6 & 25.5 & 24.2 & 23.3 & 24.2 & 22.5 \\
\hline GDP at market prices (EC\$ millions) & 933 & 987 & 1,025 & 1,091 & 1,161 & 1,156 & 1,211 & 1,277 & 1,356 & 1,438 & 1,525 \\
\hline
\end{tabular}

Sources: Ministry of Finance and Planning; and Fund staff estimates and projections.

1/ The 2005 figures follow the budget, except for capital expenditures, for which an execution rate of about 50 percent is assumed, in line with the average rate for 2001-04 2/ Salaries and wages including social security contributions, commissions, rewards, allowances, and incentives.

3/ Mainly contributions to households and international organizations.

4/ The difference between the overall balance as measured from above the line and from below the line.

5 / Net of intra-public sector debt (mainly central government debt to the NIS).

6/ Debt service excludes domestic debt amortization. 
Table 4. St. Vincent and the Grenadines: Balance of Payments Summary, 2000-2010 (Active Scenario)

\begin{tabular}{|c|c|c|c|c|c|c|c|c|c|c|c|}
\hline & \multicolumn{7}{|c|}{ Est. } & \multicolumn{4}{|c|}{ Projections } \\
\hline & 2000 & 2001 & 2002 & 2003 & $2004^{-}$ & 2005 & 2006 & 2007 & 2008 & 2009 & 2010 \\
\hline & \multicolumn{11}{|c|}{ (In millions of Eastern Caribbean dollars) } \\
\hline Current account & -61 & -98 & -112 & -204 & -279 & -319 & -308 & -294 & -281 & -264 & -256 \\
\hline Trade balance & -250 & -295 & -313 & -369 & -444 & -482 & -483 & -484 & -493 & -501 & -516 \\
\hline Exports f.o.b. & 140 & 115 & 111 & 108 & 97 & 118 & 134 & 149 & 164 & 182 & 195 \\
\hline \multicolumn{12}{|l|}{ Of which } \\
\hline Bananas & 49 & 37 & 43 & 32 & 35 & 38 & 43 & 49 & 53 & 57 & 61 \\
\hline Manufactured exports & 48 & 46 & 40 & 37 & 39 & 40 & 40 & 40 & 41 & 41 & 41 \\
\hline Imports f.o.b. & 390 & 410 & 424 & 477 & 542 & 600 & 616 & 633 & 658 & 683 & 711 \\
\hline Services (net) & 194 & 208 & 218 & 194 & 195 & 193 & 207 & 221 & 240 & 263 & 284 \\
\hline Credits & 344 & 360 & 370 & 358 & 375 & 391 & 414 & 437 & 468 & 504 & 540 \\
\hline Travel & 222 & 240 & 246 & 246 & 258 & 261 & 276 & 290 & 313 & 340 & 369 \\
\hline Other nonfactor services & 123 & 119 & 124 & 112 & 117 & 130 & 138 & 147 & 155 & 164 & 172 \\
\hline Debits & 150 & 151 & 152 & 164 & 180 & 198 & 207 & 216 & 228 & 241 & 256 \\
\hline Travel & 26 & 27 & 27 & 29 & 31 & 33 & 34 & 35 & 37 & 38 & 40 \\
\hline Other nonfactor services & 125 & 125 & 125 & 135 & 149 & 165 & 173 & 181 & 191 & 203 & 216 \\
\hline Income payments (net) & -49 & -46 & -49 & -64 & -63 & -66 & -71 & -73 & -75 & -78 & -81 \\
\hline Current transfers & 44 & 34 & 33 & 35 & 34 & 36 & 39 & 42 & 47 & 52 & 58 \\
\hline Net private transfers & 37 & 35 & 35 & 38 & 38 & 40 & 42 & 46 & 50 & 56 & 61 \\
\hline Net official transfers & 7 & -1 & -2 & -3 & -3 & -3 & -4 & -4 & -4 & -3 & -3 \\
\hline Capital and financial account & 83 & 150 & 71 & 239 & 309 & 341 & 325 & 311 & 298 & 281 & 272 \\
\hline Capital & 16 & 23 & 24 & 9 & 62 & 73 & 75 & 24 & 24 & 24 & 24 \\
\hline Financial (net) & 68 & 127 & 47 & 230 & 247 & 268 & 250 & 288 & 274 & 257 & 247 \\
\hline Official capital & 7 & 31 & 3 & 47 & 71 & 55 & 29 & 12 & 7 & 7 & 7 \\
\hline Commercial banks & -31 & 43 & -41 & -46 & -52 & -16 & -10 & -10 & -10 & -10 & -10 \\
\hline Private capital & 91 & 53 & 86 & 229 & 228 & 228 & 232 & 286 & 278 & 260 & 251 \\
\hline \multicolumn{12}{|l|}{ Of which } \\
\hline Net direct investment & 102 & 57 & 101 & 149 & 150 & 140 & 148 & 158 & 168 & 179 & 192 \\
\hline Errors and omissions & 16 & -27 & 24 & -34 & 40 & 0 & 0 & 0 & 0 & 0 & 0 \\
\hline Overall balance & 38 & 25 & -16 & 0 & 70 & 22 & 17 & 17 & 17 & 17 & 16 \\
\hline Financing & -38 & -25 & 16 & 0 & -70 & -22 & -17 & -17 & -17 & -17 & -16 \\
\hline Change in imputed reserves (increase -) & -34 & -17 & 22 & 6 & -64 & -16 & -10 & -10 & -10 & -10 & -9 \\
\hline Change in govt. foreign assets & -4 & -8 & -7 & -7 & -7 & -7 & -7 & -7 & -7 & -7 & -7 \\
\hline Other financing (interest moratorium) & 0 & 1 & 1 & 1 & 1 & 1 & 0 & 0 & 0 & 0 & 0 \\
\hline & \multicolumn{11}{|c|}{ (In percent of GDP) } \\
\hline \multicolumn{12}{|l|}{ Memorandum items: } \\
\hline Current account & -6.8 & -10.5 & -11.3 & -19.9 & -25.5 & -27.6 & -25.4 & -23.1 & -20.7 & -18.4 & -16.8 \\
\hline Exports f.o.b. & 15.4 & 12.4 & 11.3 & 10.6 & 8.9 & 10.2 & 11.0 & 11.7 & 12.1 & 12.7 & 12.8 \\
\hline Imports f.o.b. & 43.1 & 44.0 & 43.0 & 46.6 & 49.7 & 51.9 & 50.9 & 49.6 & 48.5 & 47.5 & 46.6 \\
\hline Net private transfers & 4.0 & 3.8 & 3.5 & 3.7 & 3.4 & 3.4 & 3.5 & 3.6 & 3.7 & 3.9 & 4.0 \\
\hline Foreign direct investment & 11.3 & 6.1 & 10.2 & 14.5 & 13.8 & 12.1 & 12.2 & 12.4 & 12.4 & 12.5 & 12.6 \\
\hline \multicolumn{12}{|l|}{$\begin{array}{l}\text { Indicators of diversification } \\
\text { (In percent of exports of goods and } \\
\text { nonfactor services) }\end{array}$} \\
\hline Banana exports & 10.2 & 7.8 & 8.9 & 7.0 & 7.5 & 7.5 & 7.9 & 8.3 & 8.3 & 8.3 & 8.3 \\
\hline Tourism receipts & 45.8 & 50.6 & 51.0 & 52.8 & 54.6 & 51.3 & 50.4 & 49.5 & 49.5 & 49.5 & 50.2 \\
\hline Tourism receipts & 24.5 & 25.8 & 24.9 & 24.0 & 23.7 & 22.6 & 22.8 & 22.7 & 23.1 & 23.6 & 24.2 \\
\hline Total trade & 58.5 & 56.4 & 54.3 & 57.1 & 58.6 & 62.1 & 61.9 & 61.3 & 60.6 & 60.1 & 59.4 \\
\hline Exports of goods and nonfactor services & 53.5 & 50.9 & 48.8 & 45.5 & 43.3 & 44.0 & 45.2 & 45.9 & 46.7 & 47.7 & 48.2 \\
\hline Imports of goods and nonfactor services & 59.7 & 60.2 & 58.5 & 62.5 & 66.2 & 69.0 & 68.0 & 66.5 & 65.3 & 64.2 & 63.4 \\
\hline
\end{tabular}


Table 5. St. Vincent and the Grenadines: Monetary Survey, 2000-2005

\begin{tabular}{|c|c|c|c|c|c|c|c|}
\hline & 2000 & 2001 & 2002 & 2003 & 2004 & $\begin{array}{r}\text { March } \\
2005 \\
\end{array}$ & $\begin{array}{l}\text { Proj. } \\
2005\end{array}$ \\
\hline & \multicolumn{7}{|c|}{ (In millions of Eastern Caribbean dollars) } \\
\hline Net foreign assets & 280 & 254 & 273 & 313 & 429 & 430 & 461 \\
\hline ECCB (imputed reserves) & 147 & 164 & 142 & 136 & 200 & 224 & 216 \\
\hline Commercial banks & 133 & 90 & 131 & 177 & 229 & 206 & 245 \\
\hline Net domestic assets & 355 & 401 & 436 & 409 & 383 & 410 & 400 \\
\hline Public sector credit (net) & -79 & -77 & -46 & -74 & -50 & -48 & -34 \\
\hline Central government & 62 & 44 & 86 & 47 & -5 & 0 & 32 \\
\hline ECCB & 10 & 8 & 12 & 24 & -31 & -34 & 10 \\
\hline Commercial banks & 53 & 36 & 74 & 23 & 26 & 35 & 22 \\
\hline Net credit to rest of public sector & -141 & -121 & -132 & -121 & -45 & -49 & -66 \\
\hline National Insurance Scheme & -152 & -139 & -139 & -137 & -99 & -95 & -101 \\
\hline Other & 11 & 18 & 7 & 16 & 54 & 46 & 36 \\
\hline Credit to private sector & 592 & 605 & 633 & 637 & 639 & 647 & 655 \\
\hline Net credit to nonbank financial inst. & -38 & -60 & -54 & -56 & -35 & -20 & -40 \\
\hline Other items (net) & -120 & -68 & -98 & -99 & -171 & -169 & -182 \\
\hline Broad money & 636 & 655 & 709 & 722 & 812 & 840 & 861 \\
\hline Money & 212 & 219 & 239 & 254 & 279 & 297 & 296 \\
\hline Currency in circulation & 52 & 52 & 54 & 57 & 64 & 64 & 68 \\
\hline Demand deposits & 160 & 168 & 185 & 197 & 215 & 234 & 228 \\
\hline Quasi-money & 423 & 436 & 470 & 469 & 533 & 543 & 565 \\
\hline Time deposits & 137 & 143 & 156 & 137 & 123 & 124 & 131 \\
\hline Savings deposits & 278 & 285 & 304 & 321 & 384 & 398 & 407 \\
\hline \multirow[t]{2}{*}{ Foreign currency deposits } & 9 & 8 & 10 & 10 & 26 & 20 & 28 \\
\hline & \multicolumn{7}{|c|}{ (Annual percentage change) } \\
\hline Net foreign assets & 30.1 & -9.4 & 7.4 & 14.9 & 37.0 & 29.3 & 7.5 \\
\hline Net credit to public sector & -12.4 & -2.4 & -40.7 & 61.5 & -32.6 & -0.7 & -32.3 \\
\hline Credit to private sector & 8.5 & 2.3 & 4.6 & 0.6 & 0.2 & -0.6 & 2.6 \\
\hline Broad money & 9.5 & 3.0 & 8.3 & 1.9 & 12.4 & 9.4 & 6.0 \\
\hline Money & 16.2 & 3.3 & 9.1 & 6.1 & 10.0 & 13.0 & 6.0 \\
\hline \multirow[t]{2}{*}{ Quasi-money 1/ } & 6.4 & 2.9 & 7.9 & -0.3 & 13.8 & 7.5 & 6.0 \\
\hline & \multicolumn{7}{|c|}{ (Percent contribution to growth in broad money) $2 /$} \\
\hline Net foreign assets & 11.2 & -4.1 & 2.9 & 5.7 & 16.0 & 12.7 & 3.9 \\
\hline Net domestic assets & -1.7 & 7.2 & 5.4 & -3.9 & -3.6 & -3.3 & 2.1 \\
\hline Net credit to public sector & 1.9 & 0.3 & 4.8 & -4.0 & 3.3 & 0.0 & 2.0 \\
\hline \multicolumn{8}{|l|}{ Of which } \\
\hline Central government & 1.1 & -2.9 & 6.4 & -5.5 & -7.2 & -7.0 & 4.5 \\
\hline Credit to private sector & 8.0 & 2.1 & 4.3 & 0.6 & 0.2 & -0.5 & 2.0 \\
\hline Net credit to nonbank financial inst. & 1.2 & -3.5 & 0.9 & -0.3 & 2.9 & 3.8 & -0.7 \\
\hline Other assets (net) & -12.8 & 8.3 & -4.6 & -0.2 & -10.0 & -6.7 & -1.3 \\
\hline Broad money & 9.5 & 3.0 & 8.3 & 1.9 & 12.4 & 9.4 & 6.0 \\
\hline \multicolumn{8}{|l|}{ Memorandum items: } \\
\hline Income velocity $3 /$ & 1.5 & 1.4 & 1.4 & 1.4 & 1.4 & 1.4 & 1.4 \\
\hline Deposit interest (average rate per annum) & 4.6 & 4.5 & 4.5 & 4.5 & 3.3 & 3.3 & $\ldots$ \\
\hline Lending interest rate (average rate per annum) & 11.8 & 11.9 & 11.5 & 11.5 & 9.5 & 9.5 & $\ldots$ \\
\hline Foreign currency deposits/total deposits (in percent) & 5.9 & 4.5 & 3.4 & 3.0 & 4.2 & 3.7 & $\ldots$ \\
\hline Broad money/GDP (in percent) & 70.3 & 70.2 & 71.9 & 70.5 & 74.5 & 72.6 & 74.5 \\
\hline
\end{tabular}

Sources: ECCB; Ministry of Finance and Planning; and Fund staff estimates.

1/ Including resident foreign currency deposits.

2/ Change in relation to the stock of broad money at the beginning of the period.

3/ Nominal GDP at market prices divided by liabilities to the private sector. 
Table 6. St. Vincent and the Grenadines: Medium-Term Projections, 2001-2010

\begin{tabular}{|c|c|c|c|c|c|c|c|c|c|c|}
\hline \multirow[b]{4}{*}{ Output and prices } & \multicolumn{6}{|c|}{ Est. } & \multicolumn{4}{|c|}{ Projections } \\
\hline & 2001 & 2002 & 2003 & 2004 & 2005 & 2006 & 2007 & 2008 & 2009 & 2010 \\
\hline & \multicolumn{10}{|c|}{ I. Current Policies Scenario } \\
\hline & & & & & & & & & & \\
\hline Real GDP growth at factor cost (percent change) & -0.1 & 3.2 & 3.4 & 4.3 & 5.3 & 4.5 & 4.0 & 3.3 & 2.5 & 2.5 \\
\hline Consumer prices, end-of-period (percent change) & -0.6 & 0.4 & 2.7 & 1.7 & 2.3 & 2.9 & 2.0 & 2.1 & 2.1 & 1.9 \\
\hline \multicolumn{11}{|l|}{ Nonfinancial public sector } \\
\hline \multicolumn{11}{|l|}{ Central government } \\
\hline Total revenue and grants & 30.7 & 31.7 & 31.6 & 30.3 & 31.8 & 31.7 & 31.6 & 31.5 & 31.4 & 31.4 \\
\hline Total expenditure and net lending & 32.8 & 34.0 & 34.9 & 33.7 & 38.3 & 40.2 & 38.7 & 37.4 & 37.5 & 37.7 \\
\hline \multicolumn{11}{|l|}{ Of which } \\
\hline Wages and salaries & 14.2 & 14.5 & 13.6 & 13.3 & 14.4 & 14.4 & 14.4 & 14.4 & 14.2 & 14.0 \\
\hline Interest & 2.6 & 2.6 & 2.7 & 2.5 & 3.9 & 3.7 & 4.2 & 4.4 & 4.7 & 5.0 \\
\hline Overall balance (cash basis) & -2.1 & -4.2 & -3.4 & -3.4 & -6.5 & -8.5 & -7.1 & -5.9 & -6.1 & -6.3 \\
\hline \multicolumn{11}{|l|}{ Of which } \\
\hline Primary balance & 0.5 & -1.6 & -0.6 & -0.9 & -2.7 & -4.8 & -2.9 & -1.5 & -1.3 & -1.3 \\
\hline Gross public sector debt $1 / 2 /$ & 68.2 & 70.5 & 72.8 & 78.9 & 83.9 & 89.4 & 92.2 & 93.5 & 94.4 & 95.3 \\
\hline Public sector overall balance 1/ & -0.6 & -5.8 & -3.0 & -6.4 & -10.1 & -8.6 & -7.0 & -5.7 & -5.4 & -5.2 \\
\hline \multirow[t]{2}{*}{ Public sector primary balance 1 / } & 2.3 & -3.1 & -0.3 & -3.4 & -7.3 & -5.1 & -3.1 & -1.3 & -0.8 & 0.1 \\
\hline & \multicolumn{10}{|c|}{ II. Active Scenario } \\
\hline \multicolumn{11}{|l|}{ Output and prices } \\
\hline Real GDP growth at factor cost (percent change) & -0.1 & 3.2 & 3.4 & 4.3 & 4.9 & 4.3 & 4.1 & 4.2 & 3.8 & 3.9 \\
\hline Consumer prices, end-of-period (percent change) & -0.6 & 0.4 & 2.7 & 1.7 & 2.3 & 2.9 & 2.0 & 2.1 & 2.1 & 1.9 \\
\hline \multicolumn{11}{|l|}{ Saving and investment } \\
\hline Gross domestic investment & 29.3 & 32.0 & 33.3 & 37.0 & 42.6 & 41.4 & 40.1 & 38.3 & 36.6 & 35.8 \\
\hline Public 1/ & 8.7 & 10.0 & 10.1 & 13.2 & 12.4 & 11.5 & 9.8 & 9.2 & 9.0 & 8.8 \\
\hline Private & 20.7 & 21.9 & 23.2 & 23.8 & 30.2 & 30.0 & 30.3 & 29.0 & 27.6 & 27.0 \\
\hline Gross national saving & 18.8 & 20.7 & 13.3 & 11.5 & 15.0 & 16.0 & 17.0 & 17.5 & 18.2 & 19.0 \\
\hline Public & 4.5 & 5.8 & 6.5 & 6.1 & 5.5 & 6.7 & 7.9 & 8.9 & 9.8 & 10.9 \\
\hline Private & 14.3 & 14.8 & 6.8 & 5.4 & 9.5 & 9.3 & 9.1 & 8.6 & 8.4 & 8.2 \\
\hline \multicolumn{11}{|l|}{ Nonfinancial public sector } \\
\hline \multicolumn{11}{|l|}{ Central government } \\
\hline Total revenue and grants & 30.7 & 31.7 & 31.6 & 30.3 & 31.7 & 32.6 & 33.3 & 33.4 & 33.5 & 33.6 \\
\hline Total expenditure and net lending & 32.8 & 34.0 & 34.9 & 33.7 & 35.8 & 35.1 & 34.6 & 33.6 & 33.0 & 32.2 \\
\hline \multicolumn{11}{|l|}{ Of which } \\
\hline Wages and salaries & 14.2 & 14.5 & 13.6 & 13.3 & 13.5 & 13.2 & 12.8 & 12.3 & 11.9 & 11.6 \\
\hline Interest & 2.6 & 2.6 & 2.7 & 2.5 & 3.6 & 3.8 & 3.9 & 3.6 & 3.6 & 3.2 \\
\hline Overall balance (cash basis) & -2.1 & -4.2 & -3.4 & -3.4 & -4.1 & -2.5 & -1.3 & -0.2 & 0.5 & 1.5 \\
\hline \multicolumn{11}{|l|}{ Of which } \\
\hline Primary balance & 0.5 & -1.6 & -0.6 & -0.9 & -0.5 & 1.3 & 2.6 & 3.4 & 4.1 & 4.7 \\
\hline Gross public sector debt $1 / 2$ / & 68.2 & 70.5 & 72.8 & 78.9 & 81.3 & 82.6 & 80.2 & 75.8 & 70.6 & 64.4 \\
\hline Gross public sector debt $1 /$ & 69.6 & 71.9 & 74.9 & 81.0 & 83.4 & 84.5 & 82.1 & 77.5 & 72.2 & 65.9 \\
\hline Public sector overall balance $1 /$ & -0.6 & -5.8 & -3.0 & -6.4 & -5.2 & -3.2 & -0.3 & 1.2 & 2.3 & 3.4 \\
\hline Public sector primary balance 1 / & 2.3 & -3.1 & -0.3 & -3.4 & -1.6 & 0.7 & 3.5 & 4.9 & 5.8 & 6.8 \\
\hline \multicolumn{11}{|l|}{ External sector } \\
\hline External current account & -10.5 & -11.3 & -19.9 & -25.5 & -27.6 & -25.4 & -23.1 & -20.7 & -18.4 & -16.8 \\
\hline Gross public sector external debt (end of period) & 49.1 & 46.5 & 51.3 & 54.7 & 56.4 & 56.2 & 54.2 & 51.5 & 48.4 & 45.5 \\
\hline \multicolumn{11}{|l|}{ External public debt service } \\
\hline (In percent of exports of goods and services) & 6.7 & 6.5 & 7.4 & 10.6 & 11.5 & 13.1 & 12.1 & 11.7 & 12.0 & 11.6 \\
\hline (In percent of central government revenue before grants) & 11.8 & 10.3 & 10.7 & 15.4 & 17.1 & 19.5 & 17.8 & 17.4 & 18.2 & 17.6 \\
\hline
\end{tabular}

Source: Fund staff projections.

1/ The consolidated public sector includes the central government, the National Insurance Scheme (NIS), Kingstown Board, and 10 nonfinancial public enterprises. 2/ Net of intra-public sector debt (mainly central government debt to the NIS). 
Table 7. St. Vincent and the Grenadines: Public Sector Debt, 2000-2004 1/

\begin{tabular}{|c|c|c|c|c|c|}
\hline & 2000 & 2001 & 2002 & 2003 & $\begin{array}{r}\text { Est. } \\
2004 \\
\end{array}$ \\
\hline & \multicolumn{4}{|c|}{ (In millions of Eastern Caribbean dollars at end-period) } & \\
\hline \multicolumn{6}{|l|}{ Debt stock } \\
\hline Domestic debt net of borrowing from the NIS & 179 & 178.5 & 237.1 & 220 & 264 \\
\hline Domestic debt including borrowing from the NIS & 193 & 192 & 252 & 242 & 288 \\
\hline \multicolumn{6}{|l|}{ By type of creditor } \\
\hline Other (includes NIS and insurance companies) & 45 & 27 & 50 & 89 & 94 \\
\hline \multicolumn{6}{|l|}{ By instrument } \\
\hline Treasury bills $2 /$ & 48 & 48 & 48 & 48 & 48 \\
\hline Loans & 65 & 72 & 138 & 89 & 89 \\
\hline Bonds & 60 & 60 & 60 & 60 & 90 \\
\hline Other (includes overdraft) & 21 & 12 & 6 & 45 & 60 \\
\hline Public sector external debt 3 / & 433 & 457.7 & 458.3 & 526 & 596 \\
\hline Commercial & \multicolumn{4}{|c|}{ (In percent of GDP) } & \\
\hline Total debt & 67.6 & 68.2 & 70.5 & 72.8 & 78.9 \\
\hline Domestic debt & 19.7 & 19.1 & 24.0 & 21.5 & 24.2 \\
\hline \multirow[t]{2}{*}{ External debt } & 47.8 & 49.1 & 46.5 & 51.3 & 54.7 \\
\hline & \multicolumn{4}{|c|}{ (In percent of government revenues) } & \\
\hline Total debt & 239.0 & 237.2 & 230.4 & 234.4 & 267.1 \\
\hline Domestic debt & 69.8 & 66.6 & 78.5 & 69.3 & 82.0 \\
\hline External debt & 169.2 & 170.7 & 151.9 & 165.2 & 185.1 \\
\hline \multicolumn{6}{|l|}{ Debt service } \\
\hline Total debt service & 42 & 45 & 46 & 51 & 67 \\
\hline Amortization & 16 & 17 & 19 & 22 & 35 \\
\hline In percent of government revenue excluding grants & 16.5 & 16.6 & 15.4 & 16.0 & 20.9 \\
\hline In percent export of goods and services & 8.7 & 9.4 & 9.6 & 10.9 & 14.3 \\
\hline In percent of broad money 4 / & 6.6 & 6.8 & 6.5 & 7.1 & 8.3 \\
\hline \multicolumn{6}{|l|}{ Domestic debt service } \\
\hline In percent of government revenue excluding grants & 5.8 & 4.9 & 5.0 & 5.3 & 5.5 \\
\hline In percent export of goods and services & 3.0 & 2.7 & 3.1 & 3.6 & 3.7 \\
\hline In percent of broad money 4 / & 2.3 & 2.0 & 2.1 & 2.3 & 2.2 \\
\hline \multicolumn{6}{|l|}{ External debt service } \\
\hline In percent of government revenue excluding grants & 10.7 & 11.8 & 10.3 & 10.7 & 15.4 \\
\hline In percent export of goods and services & 5.7 & 6.7 & 6.5 & 7.4 & 10.6 \\
\hline In percent of broad money 4 / & 4.3 & 4.8 & 4.4 & 4.7 & 6.1 \\
\hline Memorandum items: & & & & & \\
\hline Debt structure (in percent) & 100.0 & 100.0 & 100.0 & 100.0 & 100.0 \\
\hline Domestic & 30.9 & 29.5 & 35.4 & 31.5 & 32.5 \\
\hline Treasury bills $2 /$ & 7.6 & 7.3 & 6.7 & 6.3 & 5.4 \\
\hline Loans & 10.3 & 11.1 & 19.4 & 11.6 & 9.4 \\
\hline Bonds & 9.6 & 9.2 & 8.5 & 7.8 & 10.2 \\
\hline Other (includes overdraft) & 3.4 & 1.8 & 0.8 & 5.8 & 7.6 \\
\hline External & 69.1 & 70.5 & 64.6 & 68.5 & 67.5 \\
\hline Official bilateral & 13.3 & 12.4 & 9.9 & 10.3 & 9.4 \\
\hline Official multilateral & 24.7 & 28.1 & 27.8 & 26.2 & 22.9 \\
\hline Commercial & 31.1 & 30.0 & 26.9 & 32.0 & 35.2 \\
\hline Effective average interest rate 5 / & 4.3 & 4.3 & 4.0 & 3.9 & 4.0 \\
\hline Domestic debt & 8.1 & 6.7 & 6.8 & 6.8 & 6.6 \\
\hline External debt & 2.8 & 3.2 & 2.7 & 2.4 & 2.7 \\
\hline
\end{tabular}

Sources: Ministry of Finance and Planning; and Fund staff estimates.

1/ Net of intra-public sector debt (mainly central government debt to the NIS). The consolidated public sector includes the government, the National Insurance Scheme (NIS), Kingstown Board, and 10 nonfinancial public enterprises.

2/ Treasury bills purchased by nonresidents on the RGSM since March 2003, are included.

3/ Includes the assumption of private debt for Ottley Hall shipyard in 1999.

4/ Including foreign currency deposits.

5/ Interest payment as percent of the average debt stock at beginning and end period. 


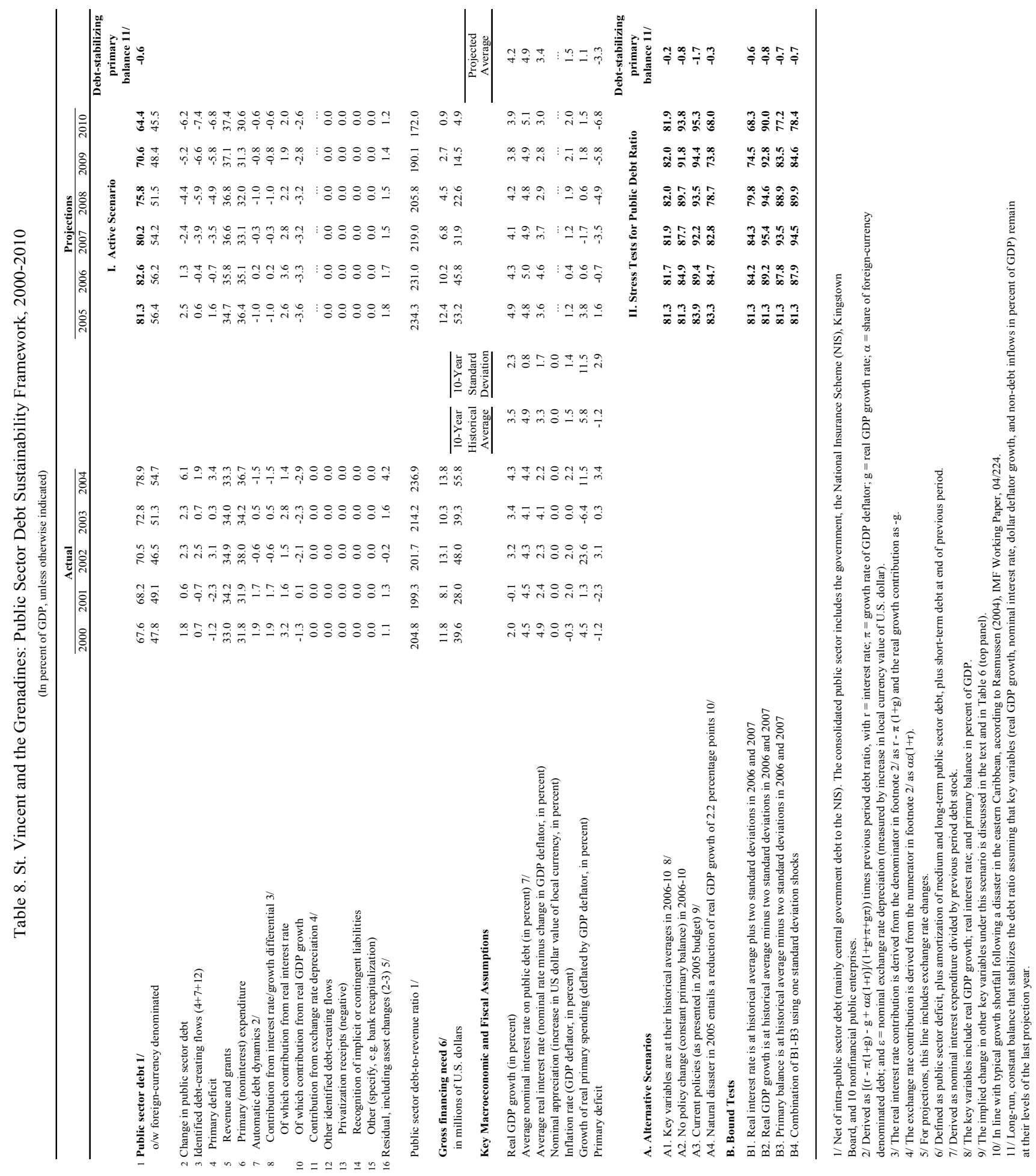




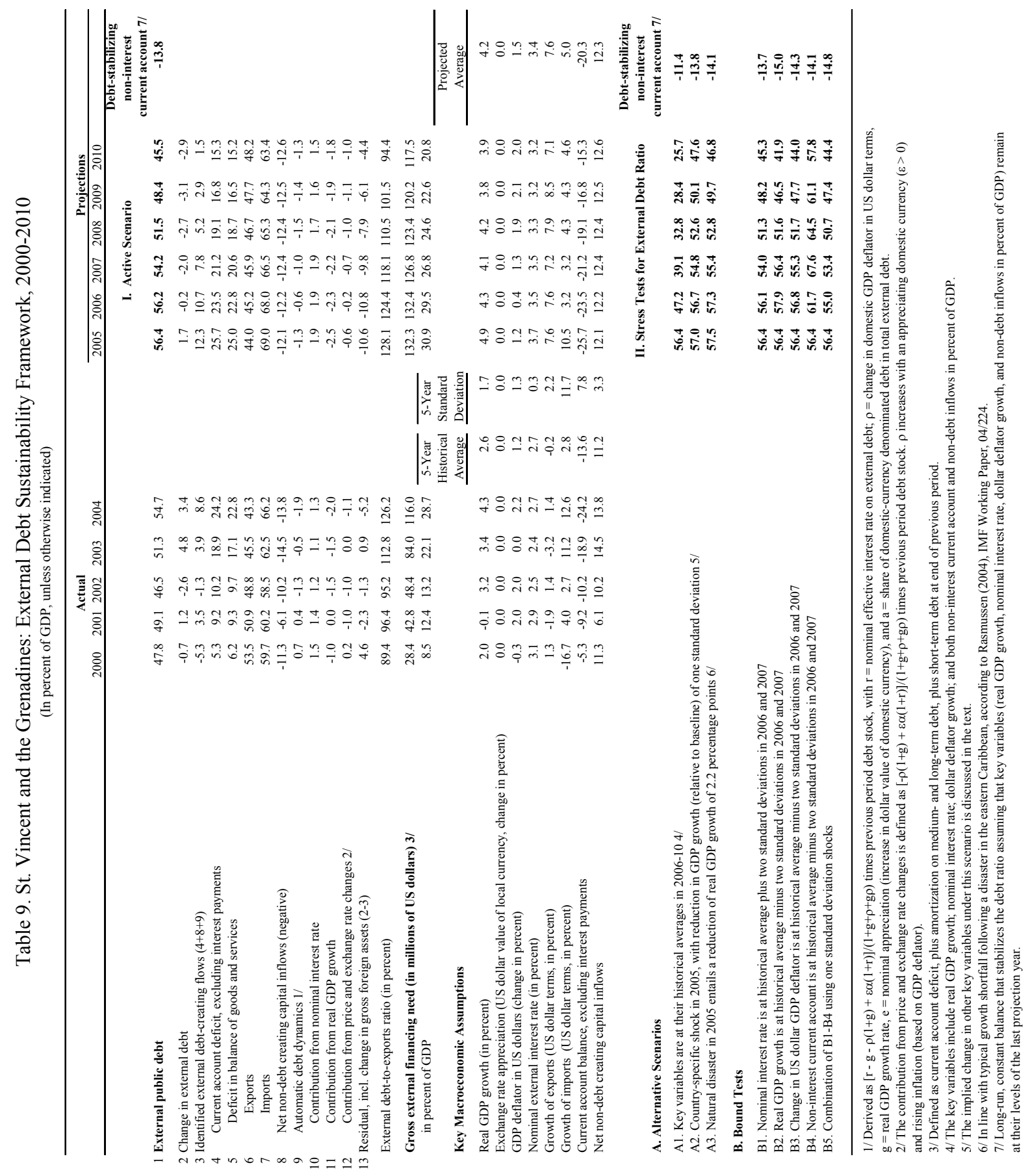


Table 10. St. Vincent and the Grenadines: Indicators of External and Financial Vulnerability, 2000-2005

(Annual percentage changes, unless otherwise specified)

\begin{tabular}{|c|c|c|c|c|c|c|}
\hline & 2000 & 2001 & 2002 & 2003 & $\begin{array}{r}\text { Est. } \\
2004\end{array}$ & $\begin{array}{l}\text { Proj. } \\
2005\end{array}$ \\
\hline \multicolumn{7}{|l|}{ External indicators } \\
\hline Merchandise exports & 4.3 & -17.4 & -3.5 & -2.8 & -10.1 & 21.4 \\
\hline Merchandise imports & -18.5 & 5.3 & 3.4 & 12.5 & 13.5 & 10.7 \\
\hline Terms of trade deterioration (-) & -3.3 & 2.9 & 2.1 & -4.2 & -3.4 & -3.2 \\
\hline Tourism earnings & -2.7 & 8.3 & 2.3 & 0.2 & 4.8 & 1.1 \\
\hline Banana export earnings & -10.2 & -25.4 & 16.0 & -24.2 & 8.7 & 7.7 \\
\hline Current account balance (in percent of GDP) & -6.8 & -10.5 & -11.3 & -19.9 & -25.5 & -27.6 \\
\hline $\begin{array}{l}\text { Capital and financial account balance (in percent of GDP) 1/ } \\
\text { Of which }\end{array}$ & 11.0 & 13.2 & 9.7 & 20.0 & 32.0 & 29.5 \\
\hline Foreign direct investment (in percent of GDP) & 11.3 & 6.1 & 10.2 & 14.5 & 13.8 & 12.1 \\
\hline \multicolumn{7}{|l|}{ Gross international reserves of the ECCB } \\
\hline In millions of U.S. dollars & 383.7 & 446.0 & 504.8 & 543.3 & 632.4 & 678.7 \\
\hline In percent of broad money & 17.4 & 19.1 & 20.2 & 19.8 & 20.4 & 20.1 \\
\hline \multicolumn{7}{|l|}{ Gross imputed reserves } \\
\hline In millions of U.S. dollars & 54.5 & 60.8 & 52.5 & 50.4 & 74.2 & 83.1 \\
\hline In percent of short-term liablilities & 510.4 & 547.6 & 467.9 & 409.5 & 410.0 & 372.6 \\
\hline Commercial banks' net foreign assets (in millions of U.S. dollars) & 49.3 & 33.3 & 48.6 & 65.6 & 84.8 & 90.7 \\
\hline External public debt (in percent of GDP) & 47.8 & 49.1 & 46.5 & 51.3 & 54.7 & 56.4 \\
\hline \multicolumn{7}{|l|}{ External debt service (in percent of exports of goods and } \\
\hline \multicolumn{7}{|l|}{ Of which } \\
\hline Interest & 2.5 & 3.0 & 2.6 & 2.5 & 3.2 & 4.1 \\
\hline $\begin{array}{l}\text { Nominal exchange rate (E.C. dollars per U.S. dollar, } \\
\text { end period) }\end{array}$ & 2.7 & 2.7 & 2.7 & 2.7 & 2.7 & 2.7 \\
\hline Real effective exchange rate depreciation (-), end period & 5.1 & 0.5 & -6.7 & -8.3 & -5.0 & 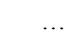 \\
\hline \multicolumn{7}{|l|}{ Financial indicators } \\
\hline Broad money & 9.5 & 3.0 & 8.3 & 1.9 & 12.4 & 6.0 \\
\hline Credit to the private sector & 8.5 & 2.3 & 4.6 & 0.6 & 0.2 & 2.6 \\
\hline \multicolumn{7}{|l|}{ Prudential indicators (in percent) } \\
\hline Capital adequacy ratio (local banks) & 11.4 & 12.2 & 12.8 & 11.6 & 8.9 & \\
\hline NPLs to total loans ratio & 10.9 & 13.0 & 11.3 & 11.1 & 9.6 & \\
\hline \multicolumn{7}{|l|}{ Of which } \\
\hline Local banks & 16.9 & 18.8 & 15.3 & 18.0 & 14.3 & \\
\hline Foreign banks & 3.0 & 5.5 & 5.1 & 2.0 & 3.9 & ... \\
\hline Loan loss provision to NPLs ratio & 35.2 & 30.4 & 41.5 & 34.1 & 34.3 & $\ldots$ \\
\hline \multicolumn{7}{|l|}{ Of which } \\
\hline Local banks & 31.9 & 30.4 & 40.0 & 26.9 & 29.8 & $\cdots$ \\
\hline Foreign banks & 59.9 & 30.4 & 48.1 & 119.4 & 53.5 & $\ldots$ \\
\hline Gross government claims to total assets ratio & 14.4 & 15.2 & 19.2 & 16.1 & 20.7 & .. \\
\hline Foreign currency deposits to total deposits ratio & 5.9 & 4.5 & 3.4 & 3.0 & 4.2 & $\ldots$ \\
\hline Net foreign currency exposure to capital (local banks) & -54.1 & 34.6 & 38.4 & 209.3 & 421.9 & $\ldots$ \\
\hline Contingent liabilities to capital (local banks) & 95.3 & 83.9 & 75.0 & 88.3 & 147.3 & $\ldots$ \\
\hline (Pre-tax) return on average assets & 0.8 & 1.0 & 1.2 & 1.0 & 1.2 & ... \\
\hline Three-month treasury bill rate $2 /$ & 7.0 & 7.0 & 7.0 & 5.5 & 5.1 & $\ldots$ \\
\hline
\end{tabular}

Sources: Eastern Caribbean Central Bank; Ministry of Finance; and Fund staff estimates and projections.

$1 /$ Includes errors and omissions.

2/ As of December 17, 2004. 
Table 11. St. Vincent and the Grenadines: Millennium Development Goals Country Profile

\begin{tabular}{|c|c|c|c|c|c|c|}
\hline & 1990 & 1995 & 2000 & 2001 & 2002 & 2003 \\
\hline 1. Eradicate extreme poverty and hunger & \multicolumn{6}{|c|}{2015 target $=$ halve $1990 \$ 1$ a day poverty and malnutrition rates } \\
\hline Prevalence of child malnutrition (percent of children under 5) &.. & 19.5 &.. & .. &.. & $\ldots$ \\
\hline 2. Achieve universal primary education & \multicolumn{6}{|c|}{2015 target $=$ net enrollment to 100} \\
\hline Net primary enrollment ratio (percent of relevant age group) &.. & .. & 91.1 & 91.9 & .. & \\
\hline Primary completion rate (percent of relevant age group) & & & 72.0 & & & 78.0 \\
\hline 3. Promote gender equality & \multicolumn{6}{|c|}{2005 target $=$ education ratio to 100} \\
\hline Ratio of girls to boys in primary and secondary education (percent) & 106.7 & .. & 103.2 & 104.3 & .. & 101.6 \\
\hline Proportion of seats held by women in national parliament (percent) & .. & .. & 5 &.. &.. & 23 \\
\hline 4. Reduce child mortality & \multicolumn{6}{|c|}{2015 target $=$ reduce 1990 under 5 mortality by two-thirds } \\
\hline Under 5 mortality rate (per 1,000 ) & 26 & 21 & 25 & 25 & 25 & 27 \\
\hline Infant mortality rate (per 1,000 live births) & 22 & 18 & 21 & 21 & 22 & 22 \\
\hline Immunization, measles (percent of children under 12 months) & 96 & 99 & 96 & 98 & 99 & 94 \\
\hline Maternal mortality ratio (modeled estimate, per 100,000 live births) &.. &.. &.. &.. & .. & .. \\
\hline Births attended by skilled health staff (percent of total) &.. & .. &.. & 100 &.. & .. \\
\hline 6. Combat HIV/AIDS, malaria and other diseases & \multicolumn{6}{|c|}{2015 target $=$ halt, and begin to reverse, AIDS, etc. } \\
\hline Prevalence of HIV, female (percent ages 15-24) & .. & .. &.. &.. & .. & .. \\
\hline Contraceptive prevalence rate (percent of women ages 15-49) &.. & .. &.. & .. & .. & .. \\
\hline Number of children orphaned by HIV/AIDS & .. &.. &.. &.. &.. & .. \\
\hline Incidence of tuberculosis (per 100,000 people) & .. & .. & 30.6 & 28 & 28.9 & 29.2 \\
\hline Tuberculosis cases detected under DOTS (percent) & .. & .. & 55.5 & 20 &.. & 38.2 \\
\hline 7. Ensure environmental sustainability & \multicolumn{6}{|c|}{2015 target $=$ various $1 /$} \\
\hline Forest area (percent of total land area) & 17.9 &.. & 15.4 & 15.4 & .. & .. \\
\hline Nationally protected areas (percent of total land area) & & & & 21.0 & 21.3 & \\
\hline $\mathrm{CO} 2$ emissions (metric tons per capita) & 0.8 & 1.2 & 1.4 & 1.4 & .. & .. \\
\hline Access to an improved water source (percent of population) &.. & .. &.. & 93.0 &.. & .. \\
\hline Access to improved sanitation (percent of population) &.. & .. &.. & 96.0. & & 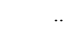 \\
\hline 8. Develop a Global Partnership for Development & \multicolumn{6}{|c|}{2015 target $=$ various $2 /$} \\
\hline Youth unemployment rate (percent of total labor force ages 15-24) & 36.3 & .. & & .. & .. & \\
\hline \multicolumn{7}{|l|}{ General indicators } \\
\hline Population (thousands) & 106.2 & 106.3 &.. & 106.3 & 106.3 & \\
\hline Gross national income (in millions of U.S. dollars) & 186.7 & 247.5 &.. & 321.8 & 330.2 & \\
\hline GNI per capita (in U.S. dollars) & 1,740 & 2,328 & 2,800 & 3,027 & 3,106 & 3,310 \\
\hline Total fertility rate (births per woman) & 2.6 & 2.3 &.. & 2.1 & 2.1 & 2.1 \\
\hline Life expectancy at birth (years) & 70.5 & 72.2 & .. & 72.9 & 72.9 & 72.9 \\
\hline Aid (percent of GNI) & 8.2 & 18.7 & .. & 2.6 & 1.4 & 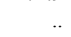 \\
\hline
\end{tabular}

Source: World Development Indicators database, April 2005, and IMF staff estimates.

1 Integrate the principles of sustainable development into country policies and programs and reverse the loss of environmental resources. Halve, by 2015 , the proportion of people without sustainable access to safe drinking water.

2/ Develop further an open, rule-based, predictable, nondiscriminatory trading and financial system. Address the Special Needs of the Least Developed and landlocked countries, and of small island developing states. Deal comprehensively with the debt problems of developing countries through national and international measures in order to make debt sustainable in the long term. In cooperation with developing countries, develop and implement strategies for decent and productive work for youth. In cooperation with pharmaceutical companies, provide access to affordable, essential drugs in development countries. In cooperation with the private sector, make available the benefits of new technologies, especially information and communications. 


\section{St. Vincent and the Grenadines: Preferential Trade Arrangement in Bananas}

St. Vincent and the Grenadines and other Windward Islands (Dominica, Grenada and St. Lucia) have a preferential trade arrangement in bananas with the European Union (EU). St. Vincent and the Grenadines is among the world's most preference-dependent economies, being heavily reliant on annual income transfers derived from quota rents (income transfers to preferred exporters from tariff revenue foregone in preference-granting markets) and higher export revenues from sales into protected overseas markets.

\section{The EU Banana Regime}

Prior to the establishment of a Single European Market in 1993, EU countries had bilateral arrangements with their ex-colonies in the Caribbean, Africa and the Pacific ("ACP" bananas). Between 1993-98, the unified EU banana regime operated on the basis of an annual ACP banana quota for duty-free export to the EU by 12 traditional producers, and an annual quota for bananas from Latin America ("dollar" bananas), subject to a tariff. Given the quantity restrictions and subsidies paid to EU banana producers, the price of bananas in the EU averaged about 80 percent more than the world price.

Several reforms to the EU banana regime have been introduced since January 1, 1999. ${ }^{1}$ A key modification is the move to a tariff-only regime (no quotas or licenses) for dollar bananas as of January 1, 2006. The EU has proposed a (quota equivalent) tariff of US\$300 (€230) per tonne on the dollar (non-ACP) bananas. The conversion of quotas into tariffs will afford some protection to ACP banana-exporting countries, but St. Vincent and the Grenadines is likely to face strong competition from more efficient African ACP producers.

In March 2005, six Latin American countries filed a World Trade Organization (WTO) challenge, arguing that the level of duty proposed by the EU under its tariff-only regime would be discriminatory against non-ACP banana producers. However, while Latin American producers have argued that such a tariff increases protection to ACP suppliers, ACP countries fear that the tariff will not prevent a supply-induced collapse in banana prices. Importantly, the WTO (Cotonou) waiver authorizing tariff preferences to the ACP countries will apply only if the new tariff is set at a level that will result in at least maintaining total market access for all WTO suppliers. In addition, by January 2006 the EU's Everything But Arms (EBA) initiative will provide for full liberalization of banana exports from non-ACP least developed countries, which will result in the further erosion of preferences to ACP banana suppliers.

\footnotetext{
${ }^{1}$ Under the current regime, Latin American exporters face a tariff of $€ 75 /$ tonne up to 2.7 million metric tons and $€ 680 /$ tonne above that level. ACP countries benefit from duty free access for 750,000 metric tonnes.
} 
The changes in the banana regime set for 2006 represent a big challenge for Windward Islands banana producers. The banana industry is privately operated mainly in small farms, with more than half the farms constituting less than 10 acres. Caribbean banana exports to the EU exhibit the highest unit costs in the world, arising from diseconomies of scale, low land productivity, high labor and transportation costs. The estimates by National Economic Research Associates (NERA) suggest that St. Vincent banana exports would remain viable at a tariff of $€ 230$ per tonne, but would likely cease at tariff levels below $€ 175$ per tonne.

\section{Policy Responses}

Policy responses undertaken by the authorities in order to adjust to the new regime include: (i) subsidizing key inputs (particularly fertilizers); (ii) paying off the debt of banana producers' associations; (ii) exempting farmers' incomes from tax; (iii) the establishment of Windward Islands Banana Development and Exporting Company Limited as a marketing agent and partial owner of the shipping service, to ensure more benefits to the farmers from various links in the chain from production to distribution and marketing; and (iv) the implementation of a Certified Growers Programme which enshrines industry standards within the framework of a contract.

\section{EU Assistance to Facilitate the Transition}

Two main sources of EU funds that have been available to Caribbean (ACP) bananaproducing countries are: (i) Special Framework of Assistance (SFA)_programmed on an annual basis since 1999 for a ten-year period, designed to boost the productivity of producers, encourage diversification (away from agriculture), and provide social protection. Under the SFA, St. Vincent and the Grenadines has been allocated assistance of $€ 33$ million between 1999 and 2004. (ii) Export revenue stabilization schemes (STABEX and FLEX) designed to compensate for declining and volatile export earnings and to target to specific capital investments within the overall national Public Sector Investment Programme of recipient countries. STABEX allocations to St. Vincent and the Grenadines in the 1993-2000 period amounted to $€ 74.1$ million. 


\title{
Medium-Term Outlook Under Alternative Fiscal Scenarios
}

\begin{abstract}
A continuation of current fiscal policies would lead to an unsustainable level of debt, and the high stock of debt is placing an increasingly heavy burden on the economy. In line with World Economic Outlook assumptions, the interest rate on new borrowings is projected to increase by $1 \frac{1}{2}$ percentage points over the next five years, from the current average of about $4 \frac{3}{4}$ percent per annum.
\end{abstract}

Two fiscal scenarios are considered-current policies and an active scenario. Under the current policies scenario, the debt stock continues to rise; under the active scenario discussed in the text, the stock of debt declines gradually over the medium term.

Current policies scenario. The authorities continue current expansionary policies with large overall imbalances that are financed commercially. Financing is assumed to continue to be available, no matter what level the debt stock reaches. In the absence of improvements in the investment climate, growth remains driven by the public sector, and slows to about $2 \frac{1}{2}$ percent over the medium term. Under this scenario, the central government primary deficit remains at about $1 \frac{1}{2}$ percent of GDP and public debt rises to over 95 percent of GDP by 2010 (see Table 6, Scenario I).

Active scenario. A fiscal adjustment of $2 \frac{1}{2}$ percent is assumed for 2005 (see main text) and further adjustment over the medium term, with the central government primary balance moving from a deficit of 0.9 percent of GDP in 2004 to a surplus of 4.7 percent of GDP in 2010. Trend growth accelerates with the greater activity in the private sector, and is estimated at 4 percent of GDP over the medium term. In this scenario, the debt stock would fall to about 64 percent of GDP by 2010 (see Table 6, Scenario II and Table 7). 


\section{St. Vincent and the Grenadines-Relations with the Fund}

(As of April 30, 2005)

I. Membership Status: Joined December 28, 1979; Article VIII

II. General Resources Account:

SDR Million

Percent of Quota

Quota

8.30

100

Fund holdings of currency

7.80

93.98

Reserve position in the Fund

0.50

6.02

III. SDR Department:

SDR Million

Percent of Allocation

Net cumulative allocation

0.35

0.01

100.00

Holdings

IV. Outstanding Purchases and Loans: None

V. Latest Financial Arrangement: None

\section{Projected Obligations to the Fund:}

\begin{tabular}{|c|c|c|c|c|c|}
\hline & \multirow[b]{2}{*}{2005} & \multicolumn{4}{|c|}{ Forthcoming } \\
\hline & & 2006 & 2007 & 2008 & 2009 \\
\hline Principal & 0.0 & 0.0 & 0.0 & 0.0 & 0.0 \\
\hline Charges/Interest & $\underline{0.01}$ & $\underline{0.01}$ & $\underline{0.01}$ & $\underline{0.01}$ & $\underline{0.01}$ \\
\hline Total & $\underline{0.01}$ & $\underline{0.01}$ & $\underline{0.01}$ & $\underline{0.01}$ & $\underline{0.01}$ \\
\hline
\end{tabular}

\section{Exchange Arrangement:}

St. Vincent and the Grenadines is a member of the Eastern Caribbean Central Bank (ECCB), which manages monetary policy and the exchange system for its eight members. The common currency, the Eastern Caribbean dollar, has been pegged to the U.S. dollar at the rate of EC\$2.70 per U.S. dollar since July 1976. In practice the ECCB has operated like a quasi-currency board, maintaining foreign exchange backing of its currency and demand liabilities of close to 100 percent. The exchange system is free of restrictions on the making of payment and transfers for current international transactions. The exchange control on the EC $\$ 250,000$ limit on purchase of foreign exchange without the authorization of the Ministry of Finance was removed in December 2004. 


\section{Last Article IV Consultation:}

The last Article IV consultation was concluded by the Executive Board on May 5, 2004. St. Vincent and the Grenadines is on the 12-month consultation cycle. The authorities have not accepted the Fourth Amendment of the Fund's Articles of Agreement.

\section{FSAP Participation, ROSCs, and OFC Assessments:}

St. Vincent and the Grenadines participated in the regional ECCU FSAP conducted in September and October 2003. The Financial System Stability Assessment is IMF Country Report 04/293. A ROSC for Basle Core Principles Assessment of St. Vincent and the Grenadines' offshore banking sector was completed in April 2004 (IMF Country Report 04/305).

X. Technical Assistance: (2003-present)

\section{Caribbean Regional Technical Assistance Centre (CARTAC):}

- March-May 2003. The Stabilization and Adjustment Technical Assistance Programme (SATAP) programme assists ECCB member countries develop home grown stabilization and adjustment programmes (SAPs) within an agreed financial programming framework governed by the ECCU Monetary Council's fiscal benchmarks and debt sustainability criteria. Projections were undertaken under an active scenario of St. Vincent and the Grenadines that incorporated measures which allowed the projected outcomes to satisfy the debt sustainability criteria.

- May 2003. A mission assisted the Offshore Financial Authority (OFA) with a file review of ten offshore banks.

- $\quad$ November 2003. A mission held discussions with authorities on the International Banks Act.

- $\quad$ November 2003. An initial consultancy mission was conducted to develop a Supply and Use Table (SUT) in preparation for rebasing of the national accounts.

- $\quad$ November 2003-February 2004. Training on Customs Valuation comprising valuation complexities and post release audit was delivered to customs officers.

- January 2004. At the authorities' request CARTAC has prepared an action plan for VAT introduction.

- May 2004. A mission discussed the International Banks Act with the authorities. 
- May 2004. Staff emphasized the use of alternative compilation strategies for the Supply and Use Table (SUT) through the use of existing source data, relying more on better organization of data to increase their use in analysis.

- June 2004. A mission assisted staff of the International Financial Service Authority (IFSA) with the analysis of financial statements and other regulatory information submitted by three banks and identified areas for further work by IFSA when they conduct the on-site inspections.

- July-August 2004. A macroeconomic programming workshop was conducted and a draft report was prepared on the exercise.

- October/November 2004. A mission provided assistance with development of regulation on capital adequacy, risk management guidelines and guidelines on corporate governance, accounting and auditing, related party transactions, large exposures and asset classification along the lines of those currently under development with the ECCB.

- December 2004. A mission assisted in the development of export-import price indices in the compilation of constant price estimates of GDP. 


\title{
St. Vincent and the Grenadines-Relations with the World Bank Group
}

\author{
(As of May 25, 2005)
}

The World Bank's Management presented to its Board the Eastern Caribbean Sub-Region Country Assistance Strategy (CAS), on June 28, 2001. The CAS, which covers FY 2002-06, proposes new commitments of US\$107 million for five borrowing member states of the Organization of the Eastern Caribbean States (OECS), including St. Vincent and the Grenadines. The main goals of the strategy are to reduce income insecurity and vulnerability at the national and household levels, and build human and institutional capacity to meet the challenging economic and social environment facing these small states. Most new projects are being provided under a sub-regional umbrella mechanism using horizontal Adaptable Program Loans (APLs), and in close collaboration with sub-regional organizations and external partners.

The World Bank is currently preparing a new Country Assistance Strategy (CAS) for the Eastern Caribbean (OECS) sub-region. This new CAS will cover the period FY 2006-09.

\section{Projects}

There are four active World Bank projects in St. Vincent and the Grenadines for a net commitment of approximately US\$22.3 million.

The St. Vincent and the Grenadines Disaster Management Project, approved in May 2002, is part of a regional program for the five OECS borrowing countries to fortify, reconstruct, and/or rehabilitate key economic and social infrastructure and facilities, in order to minimize damage or disruption caused by future natural and man-made disasters, and to speed emergency recovery following such disasters. Additionally, the project is expected to strengthen the countries' institutional capacity to prepare for and respond to disaster emergencies efficiently and effectively. The total program is US\$46 million, and the St. Vincent and the Grenadines component is US\$5.9 million.

On March 8, 2002, the World Bank approved US\$20.9 million in loans and credits to support Emergency Recovery Projects in Dominica, Grenada, St. Kitts and Nevis, St. Lucia, and St. Vincent and the Grenadines. The projects support efforts aimed at fostering recovery from the fallout of the events of September 11, 2001, including: (i) efforts to safeguard the productive capacity of the tourism sector by securing energy imports; (ii) investments to enhance security at airports and ports; and (iii) the development of institutional capacity to develop security programs as mandated by international civil aviation and maritime transport agencies. The Bank’s support to St. Vincent and the Grenadines under this project is US\$3.2 million.

The St. Vincent and the Grenadines Education Reform Project, was approved in June 2004 for US\$6.2 million. The overall objective of this project is to build human capital to contribute to the diversification of the economy and more sustainable growth. This 
objective will be achieved by: (i) increasing equitable access to secondary education;

(ii) improving the quality of the teaching and learning process, with more direct interventions at the school level and a focus on student-centered learning, and (iii) strengthening management of the sector and governance of schools.

The HIV/AIDS Prevention and Control Program, which was approved in July 2002, is funded under the Multi-Country APL for the Caribbean Region. The project's objectives are: (i) curbing the spread of HIV/AIDS epidemic; (ii) reducing the morbidity and mortality attributed to HIV/AIDS; (iii) improving the quality of life for persons living with HIV/AIDS (PLWAs); and (iv) developing a sustainable organizational and institutional framework for managing the HIV/AIDS epidemic over the longer term. The Bank's support to St. Vincent and the Grenadines under this project is for US\$7.0 million.

\section{ECONOMIC AND SECTOR WORK}

The Bank has recently completed a series of analytical reports relating to: public sector capacity in the OECS including the Institutional and Organizational Capacity Review, the OECS Procurement Assessment Review, the OECS Financial Accountability Assessment, and a Public Expenditure Review. In conjunction with the IMF, a Financial Sector Assessment Program was completed in 2004. In addition, the Bank recently completed an OECS study on Growth and Competitiveness, as well as a Caribbean wide study on Growth and Competitiveness. A review of large scale energy options for the OECS, under the Energy Sector Management Assistance Program is ongoing. St. Vincent and the Grenadines also stands to benefit from ongoing Caribbean-wide work on Social Protection.

III. Financial Relations

(In millions of U.S. dollars)

\begin{tabular}{lccc} 
Operation & Original Principal & Available/1 & Disbursed $/ 1$ \\
\hline $\begin{array}{l}\text { TELECOM AND ICT DEVELOPMENT- } \\
\text { ST. VINCENT AND THE GRENADINES }\end{array}$ & 0.54 & 0.57 & 0.0 \\
\hline $\begin{array}{l}\text { EMERGENCY RECOVERY PROJECT - } \\
\text { ST. VINCENT AND THE GRENADINES }\end{array}$ & 3.20 & 1.41 & 2.24 \\
$\begin{array}{l}\text { EDUCATION REFORM PROJECT - } \\
\text { ST. VINCENT AND THE GRENADINES }\end{array}$ & 6.20 & 6.11 & 0.32 \\
$\begin{array}{l}\text { DISASTER MANAGEMENT - ST. VINCENT } \\
\text { AND THE GRENADINES }\end{array}$ & 5.91 & 5.04 & 1.55 \\
$\begin{array}{l}\text { HIV/AIDS PREVENTION AND CONTROL } \\
\text { PROGRAM - ST. VINCENT AND THE }\end{array}$ & & & \\
$\begin{array}{l}\text { GRENADINES } \\
\text { TOTAL }\end{array}$ & 7.00 & 6.96 & 0.32 \\
1/ Amounts may not add up to Original Principal due to changes in the SDR/US exchange rate since signing.
\end{tabular}


Disbursements and Debt Service (Fiscal Year Ending June 30)

\begin{tabular}{|c|c|c|c|c|c|c|c|c|c|}
\hline & \multicolumn{8}{|c|}{ Actual } & \multirow{2}{*}{$\begin{array}{c}\text { Projections } \\
2005\end{array}$} \\
\hline & 1997 & 1998 & 1999 & 2000 & 2001 & 2002 & 2003 & 2004 & \\
\hline Total disbursements & 0.1 & -0.0 & 0.2 & 0.0 & 0.4 & 1.5 & 1.7 & 1.2 & 2.6 \\
\hline Repayments & 0.2 & 0.2 & 0.1 & 0.1 & 0.1 & 0.1 & 0.3 & 0.1 & 0.3 \\
\hline Net disbursements & -0.1 & -0.2 & 0.1 & -0.1 & 0.3 & 1.3 & 1.4 & 1.1 & 2.3 \\
\hline Canceled & 0.0 & 0.7 & 0.0 & 0.0 & 0.0 & 0.0 & 0.0 & 0.0 & 0.0 \\
\hline Interest and fees & 0.1 & 0.1 & 0.1 & 0.1 & 0.1 & 0.1 & 0.1 & 0.1 & 0.2 \\
\hline
\end{tabular}




\section{St. Vincent and the Grenadines-Relations with the Caribbean Development Bank} (As of April 30, 2005) undisbursed.

CDB has approved loans totalling US\$150.3 million, of which US\$54.2 million are

\section{Major Projects:}

1. Third Power Project - is geared towards improving the operational capability and reliability of St. Vincent Electricity Services Limited (VINLEC) in order to meet the projected demand for electricity to the end of 2008.

2. Basic Education Project (Second Loan) - is to assist GOSVG in enhancing the learning environment through improvements in delivery of pre-primary and basic education within SVG. Components include the construction of four schools; the upgrading of knowledge, skills and competencies of education managers, planners and supervisors; and professional development of teachers, trainers, principals and other key school personnel.

3. $\quad 3^{\text {rd }}$ Road Project: Windward Highway - to reconstruct approximately 23 kilometres of the Windward Highway; the realignment of the road at 6 locations; widening and lining of the Byera tunnel to provide pedestrian access; and rehabilitation of 13 bridges.

4. Student Loan Scheme (Sixth Loan) - to provide loans to student for upgrading skills at the professional, technical and vocation levels.

5. Agricultural and Industrial Line of Credit - to provide the St. Vincent and the Grenadines Development Bank (SVGDB) with long-term resources for on-lending to private sector sub-borrowers in the productive sectors of the economy.

6. Caribbean Court of Justice - to provide for the establishment and operation of a final Court of Appeal to replace the Judicial Committee of the Privy Council and to act as a final arbiter in disputes arising between CARICOM member states or between a CARICOM national and another country.

\section{Current Portfolio}

(In millions of U.S. dollars)

\begin{tabular}{lll}
\hline & Approved & Undisbursed \\
\hline Third Power Project & 18.3 & 18.3 \\
Basic Education (Second Loan) & 17.6 & 17.6 \\
$3^{\text {rd }}$ Road Project - Windward Highway & 10.6 & 10.4 \\
Student Loan Scheme (Sixth Loan) & 3.5 & 3.0 \\
Agricultural and Industrial Line of Credit & 3.0 & 3.0 \\
Line of Credit (Third Loan) & 2.4 & 0.8 \\
OECS Solid Waste Project (add. Loan) & 2.0 & 0.4 \\
\hline
\end{tabular}




\section{LOAN DISBURSEMENT}

(in millions of U.S. dollars)

\begin{tabular}{|c|l|l|l|l|l|}
\hline & $\mathbf{2 0 0 1}$ & $\mathbf{2 0 0 2}$ & $\mathbf{2 0 0 3}$ & $\mathbf{2 0 0 4}$ & $\mathbf{2 0 0 5}^{\mathbf{1}}$ \\
\hline Net Disbursement & 3.42 & 3.8 & 0.96 & 1.54 & -1.00 \\
\hline Disbursement & 5.42 & 5.93 & 3.88 & 4.61 & 0.11 \\
\hline Amortization & 2.00 & 2.13 & 2.92 & 3.07 & 1.11 \\
\hline Interest and charges & 1.90 & 1.82 & 1.92 & 1.99 & 0.87 \\
\hline Net resource flow & 1.52 & 1.98 & -0.96 & -0.45 & -1.87 \\
\hline
\end{tabular}

1/ As of April 30. 


\section{St. Vincent and the Grenadines-Statistical Issues}

St. Vincent and the Grenadines has been participating in the General Data Dissemination System (GDDS) since September 2000, and its metadata are posted on the Dissemination Standards Bulletin Board (DSBB). St. Vincent and the Grenadines' statistical database remains weak in terms of coverage, consistency, periodicity, and timeliness. Major improvements in all areas are needed to facilitate effective surveillance. Efforts to address the weaknesses in the statistical base have been hampered by low response rates to surveys (less than 50 percent), and high turnover of staff.

Prices: Data on the consumer price index (CPI) are reported regularly with a two-month lag. CARTAC assisted in linking the 1981-based CPI series to the 2001-based one. This was part of the Fund assisted program on Constructing Weights for the Harmonized Consumer Price Index in the ECCU. St. Vincent and the Grenadines conducted the Household Budget and Expenditure Survey (HBES) in 1995/96, whilst all the other five ECCU member countries conducted HBES surveys for 1998/99. Compilers thus will have to use a method for updating the St. Vincent expenditure weights to 1998/99 to properly align its CPI with those of the other ECCU member countries before all eight are combined into an ECCU-harmonized CPI.

Labor: The Statistical Office has not published official data on unit labor costs and employment. Results of the 2001 population census have been analyzed and published.

National Accounts: National accounts data by sector are provided with one-year lag, and the coverage of economic activity in the informal sector is inadequate. There is a need to fully upgrade compilation of statistics from the 1968 System of National Accounts to the 1993 System of National Accounts. In addition, data on GDP broken down by type of expenditure are not available at constant prices, while data at current prices are not reliable due to weaknesses in estimating gross capital formation. Private final consumption expenditure is estimated as a residual.

Public finance: The IMF publishes annual data for the consolidated general government in the GFS Yearbook, with the 2004 edition showing annual data to 2003. Only cash data are shown, with a detailed classification of revenue and a functional, but not economic type, classification of expenses. No financing information is provided and the only balance sheet data shown are domestic and foreign liabilities for 2001. Due to delays in reporting capital expenditures by some ministries, quarterly revenue and expenditure data for the central government are provided to the Fund with some lag. Discrepancies exist between the fiscal and monetary accounts, between above and below the line for budget data, and between financing data and debt accumulation. There is a need to reconcile these discrepancies. Although domestic debt figures are now available following implementation of the CS-DRMS system, the domestic debt amortization figures are incomplete. The public enterprises financial reports are not timely, with about a two-year lag. 
Monetary statistics: Monetary data are compiled by the ECCB on a monthly basis. The data are reported regularly to the Fund, although the timeliness of data could be improved. The monetary and financial data do not include other deposit-taking institutions such as the credit unions. The ECCB is aware of the need to improve the coverage of the financial statistics and has taken steps to collect data on credit unions (the savings and loans of credit unions account for 20-30 percent of market share).

Balance of payments: Estimates for St. Vincent and the Grenadines are currently provided on an annual basis by the ECCB, using a format that is not fully consistent with BPM5. The latest published data in the IFS (March 2005) refer to 2002. There is a need to improve the compilation of capital and financial account transactions in the balance of payments. In addition, the recording of the stock of private and public debt should be improved. 

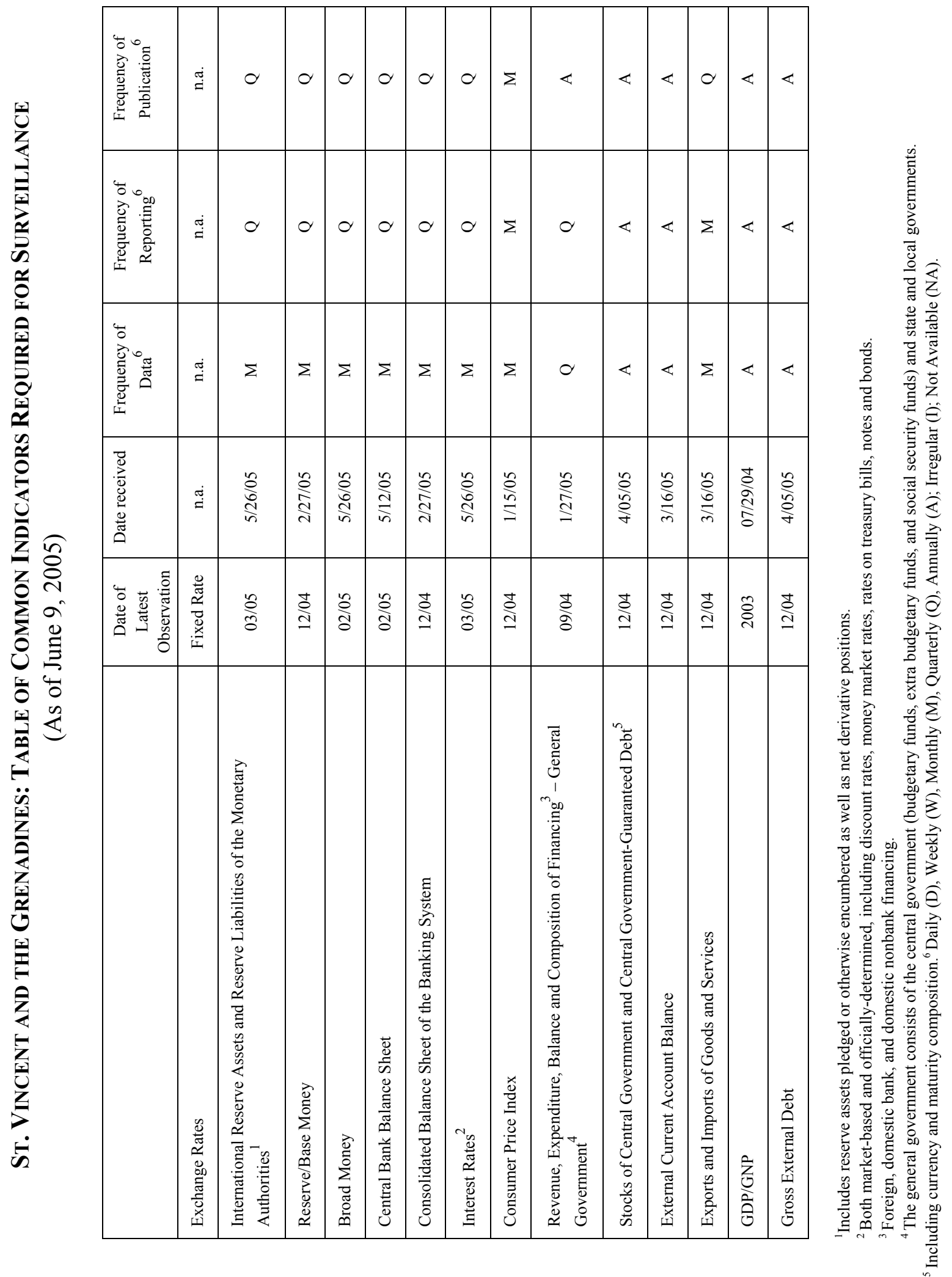


\section{INTERNATIONAL MONETARY FUND}

EXTERNAL

Public Information Notice

RELATIONS

DEPARTMENT

Public Information Notice (PIN) No. 06/60

FOR IMMEDIATE RELEASE

International Monetary Fund

June 2, 2006

$70019^{\text {th }}$ Street, NW

Washington, D. C. 20431 USA

\section{IMF Executive Board Concludes 2005 Article IV Consultation with St. Vincent and the Grenadines}

On July 13, 2005, the Executive Board of the International Monetary Fund (IMF) concluded the Article IV consultation with St. Vincent and the Grenadines. ${ }^{1}$

\section{Background}

St. Vincent and the Grenadines' economy grew rapidly during the 1980s, but has slowed significantly since the early 1990s. Factors inhibiting the growth performance over the past decade include a series of adverse shocks — the erosion of trade preferences, poor weather and natural disasters, the September 112001 attack which had a negative impact on the important tourism sector, and the decline in overseas development assistance. In order to accelerate growth, the authorities began in the late 1990s to implement expansionary fiscal policies, leading to persistent public sector imbalances. As a result, the stock of public debt rose from less than 50 percent of GDP in 1997 to almost 80 percent of GDP in 2004.

Economic activity has strengthened, with real GDP growing by 4.3 percent in 2004 , and further acceleration expected in 2005 . This improved performance was underpinned by a supportive external environment, strong growth in tourism, and a rebound in construction and agriculture sectors. However, fiscal imbalances expanded in 2004, with the primary balance of the central government deteriorating by $1 / 3$ of one percent of GDP to reach almost 1 percent of GDP in 2004. The approved budget for 2005 is likely to lead to a significant further deterioration in the

${ }^{1}$ Under Article IV of the IMF's Articles of Agreement, the IMF holds bilateral discussions with members, usually every year. A staff team visits the country, collects economic and financial information, and discusses with officials the country's economic developments and policies. On return to headquarters, the staff prepares a report, which forms the basis for discussion by the Executive Board. At the conclusion of the discussion, the Managing Director, as Chairman of the Board, summarizes the views of Executive Directors, and this summary is transmitted to the country's authorities. 
fiscal accounts, mainly due to a large increase in discretionary spending (particularly on wages and capital spending), despite an increase in revenues. This is likely to lead to a further rise in public debt levels, reaching almost 81 percent of GDP in 2005.

The external current account deficit widened substantially in 2004 to about 26 percent of GDP, and is likely to deteriorate further in 2005. The large rise in the current account deficit in 2004 was driven by a decline in exports, and a general rise in imports, especially of energy products and building materials. In 2005 the current account is expected to continue to deteriorate, mainly on account of higher imports due to additional public capital expenditure and rising oil import costs, despite a rebound in banana export earnings.

Reflecting the continued recovery in economic activity, monetary liabilities and domestic credit have rebounded. Broad money (M2) growth accelerated in 2004, as deposits with the banking sector rose strongly. While net lending to the central government continued to decline in 2004, credit to the private sector rose marginally. Net foreign assets of the banking system surged, as both commercial banks' net foreign assets and St. Vincent and the Grenadines' implicit reserves at the ECCB increased substantially.

Financial sector indicators have improved in recent years. Supervision and regulation of the offshore sector has strengthened, assisted by the adoption of the International Bank Act in 2004. Prudential indicators point to weaknesses in the domestic banking sector, although efforts are ongoing to improve bank balance sheets. Indigenous banks suffer from a number of weaknesses, including total capital-to-risk-weighted assets that are considerably below the ECCU average, a large portfolio of nonperforming loans, and high public sector exposures.

Progress has been made in broader structural reforms. With the support of the European Union, the authorities have continued in their efforts to diversify production into non-banana agriculture (under the Agricultural Diversification Program). Progress has also occurred in domestic pricing of energy inputs and in tax administration, as well as in efforts to improve labor skills through training programs. A one-stop shop for foreign investment enquiries and facilitation has been created with the establishment of the National Investment Promotions Incorporated. The authorities have restated their intention to bolster revenue-raising by the introduction of a value-added tax and market valuation-based property taxation in 2007.

\section{Executive Board Assessment}

Executive Directors noted that economic activity has strengthened in 2004, despite the impact of Hurricane Ivan, and welcomed the prospects for accelerated growth in 2005. The improved performance has been aided by sustained activity in construction and a favorable external environment. The tourism sector has expanded rapidly with the increase in stay-over arrivals during 2004. Prospects for further expansion in the sector, including tourism-related services and associated construction activity, appear strong and are likely to underpin economic growth for the next several years. Directors saw the main challenges going forward to be to accelerate growth and reduce poverty, while restoring fiscal and external viability and reducing the debt 
burden. They also underscored the importance of further regional cooperation so as to help the country reap the full potential benefits of the ECCU.

While traditionally among the most fiscally prudent of the ECCU countries, Directors noted that St. Vincent and the Grenadines' public debt has increased significantly in recent years, in substantial part due to the assumption of a large private external loan by the government. They also observed that the fiscal outlook for 2005 is quite difficult, and urged the authorities to address the weakening fiscal situation by implementing appropriate measures to reduce public borrowing. They noted that, in the absence of a strong effort to address the growing fiscal imbalances, the public debt could be placed on an unsustainable path. Directors stressed that such a high debt level raises the risk from adverse shocks, and acts to constrain the government's future ability to engage in counter-cyclical fiscal policy. In light of these considerations, Directors underscored the need for strong fiscal action to reduce debt sustainability risks, while making room for social and other priority outlays. Pointing to the need to strengthen infrastructure and poverty alleviation, some Directors supported the need for strategic investments that would entail a short-term increase in the fiscal deficit.

Directors welcomed the government's plans to improve tax policy and administration in order to broaden the tax base and reduce concessions. They regarded the planned adoption of a value added tax and market-based property taxation as steps in the right direction. They cautioned, however, that more needs to be done, particularly in the area of tax concessions. Directors advised the authorities to seek greater regional cooperation, in order to have a common approach to tax concessions, and thereby avoid region-wide tax competition. The importance of improving the transparency of concessions was also noted.

On the expenditure side, Directors emphasized the need to control the wage bill, which has increased rapidly in recent years due to an increase in civil service employment.

They recommended the adoption of a wide-ranging civil service reform, in order to ensure that expenditure consolidation can be achieved without impinging on the quality of service provision. At the same time, Directors recommended that the authorities undertake cost-benefit analyses and prioritization of the extremely high level of proposed public investment projects.

Directors were encouraged by the good progress made by the authorities in boosting their disaster mitigation and preparedness, through the drafting of a national disaster plan, and implementation of a national building code. They recommended that the authorities undertake greater efforts to transfer disaster risk, including through regional insurance pools, enhanced insurance of public buildings and infrastructure assets, and better enforcement of building codes.

Directors observed that the financial sector remains vulnerable to adverse shocks. They urged that measures be taken to strengthen the effectiveness of financial sector supervision, such as through the approval of amendments to the Uniform Banking Act and development of a broad supervisory framework to regulate all nonbank financial intermediaries (including insurance companies, credit unions and other near banks). Given the systemic importance of the 
state-owned National Commercial Bank, the government was encouraged to continue its efforts to address management and asset quality weaknesses. Directors welcomed the authorities' efforts to enhance supervision of the offshore sector, and encouraged them to continue to ensure the consistency of the regulatory and supervisory frameworks with international best practices.

Directors noted the need to strengthen the quality, coverage, timeliness, and frequency of the statistical database to facilitate policymaking and effective surveillance. They encouraged the authorities to address these data problems, and stressed that improvements are particularly needed in the coverage of the national accounts, in data used to monitor labor market and poverty developments, and in the financial data of public enterprises and statutory bodies.

Directors commended the government's efforts at increasing opportunities for public discussion of policy choices, especially through the formation of the National Economic and Social Development Council. They welcomed the home-grown Interim Poverty Reduction Strategy Paper, as it encapsulates the desire of the government to build a public consensus behind the key objective of reducing poverty, and the need for greater transparency. Directors commended the authorities for their efforts in tackling the problems associated with the erosion of trade preferences for the banana industry, and welcomed the government's hosting of the International Conference on prospects for the sector. Directors noted that increased efforts to disseminate and explain economic developments and policy choices would also deepen the public's understanding of, and support for, structural reforms.

Public Information Notices (PINs) form part of the IMF's efforts to promote transparency of the IMF's views and analysis of economic developments and policies. With the consent of the country (or countries) concerned, PINs are issued after Executive Board discussions of Article IV consultations with member countries, of its surveillance of developments at the regional level, of post-program monitoring, and of ex post assessments of member countries with longer-term program engagements. PINs are also issued after Executive Board discussions of general policy matters, unless otherwise decided by the Executive Board in a particular case. 
'St. Vincent and the Grenadines: Selected Economic Indicators, 2000-2005

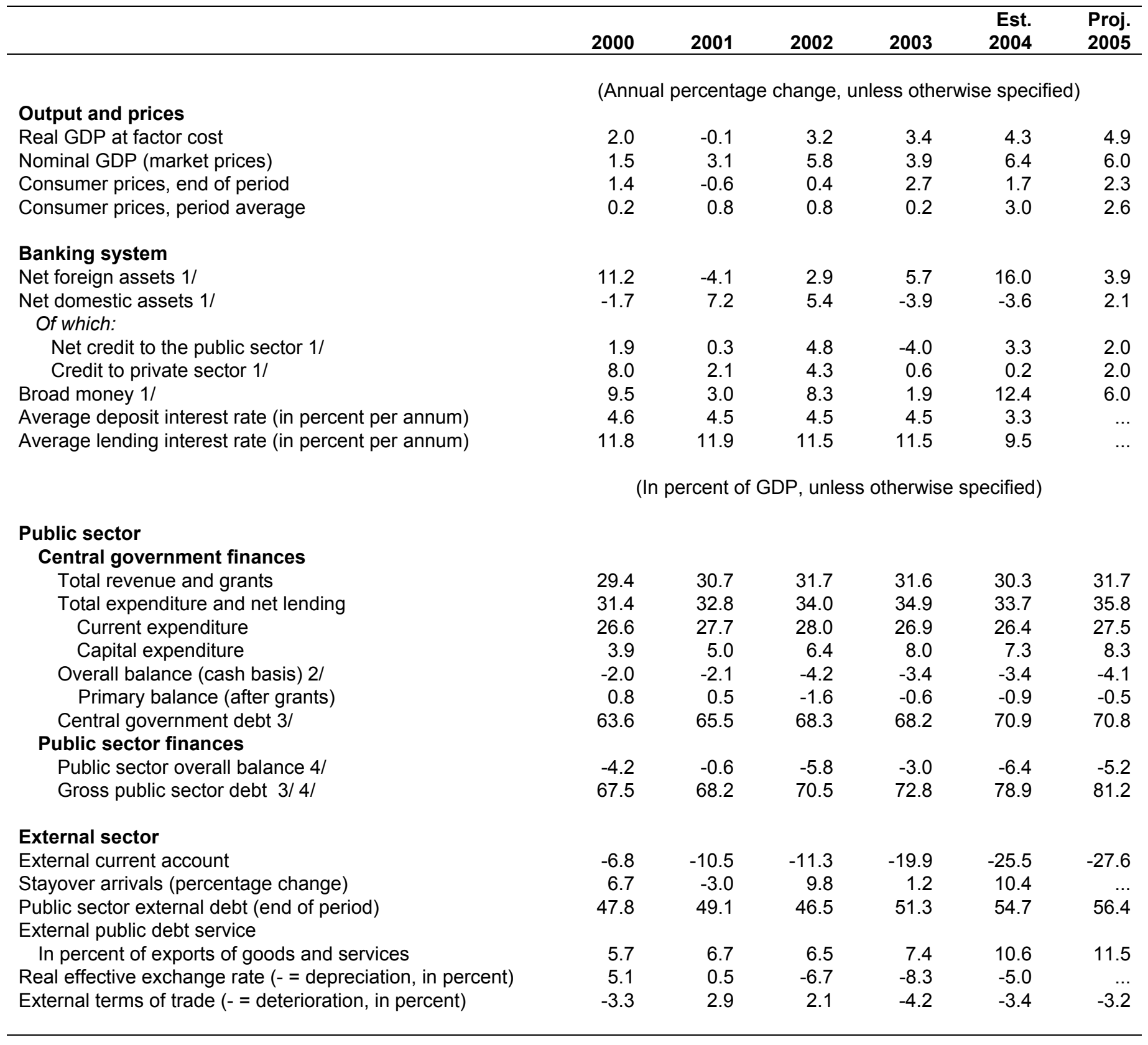

Sources: Eastern Caribbean Central Bank, Ministry of Finance and Planning; Banana Growers' Association, and Fund staff estimates and projections.

1/ Annual changes relative to the stock of broad money at the beginning of the period.

$2 /$ Includes the difference between the overall balance as measured from above the line and from below the line (i.e. financing), which may include float and unidentified discrepancies.

3/ Net of intra-public sector debt (mainly central government debt to the NIS).

4/ The consolidated public sector includes the central government, the National Insurance Scheme (NIS), Kingstown Board, and 10 nonfinancial public enterprises. 